Kamila Staśko-Mazur

ORCID: 0000-0003-4383-418X

Uniwersytet Wrocławski

\title{
Oprawa graficzna piosenek popularnych Władysława Szpilmana jako świadectwo praktyk artystyczno-wydawniczych i przemian w projektowaniu okładek
}

Abstrakt: Celem artykułu jest przedstawienie oprawy graficznej druków piosenek popularnych Władysława Szpilmana jako źródeł ukazujących różne formy zdobnictwa i graficzne trendy oraz przemiany w dziedzinie projektowania okładek nut muzyki popularnej.

Prezentacja wybranych druków z rozległego dorobku piosenkarskiego artysty umożliwia przypomnienie przedwojennych wydawnictw (Nowa Scena, Wydawnictwo Muzyczne Arcta, Wydawnictwo Eugeniusza Kuthana, Ton) i zobrazowanie problemu zaniku prywatnych i spółdzielczych oficyn na rynku wydawniczym (powojenne wyparcie wydawnictw niepaństwowych). Ukazuje charakterystyczne formy zdobienia okładek piosenek artysty w kolejnych okresach (formy reklamujące, bordiurowo-winietowe, literniczo-typograficzne, ,plakatowe”) i zawiłości procesów związanych z ideologizującą rolą sztuki (na przykład różne sposoby ilustrowania pieśni okresu socrealistycznego dla nabywcy indywidualnego i dla zespołów czy skromne i jednorodne druki wydawnictwa Czytelnik).

Po wojnie sam kompozytor sekunduje pomysłowi stworzenia wydawnictwa typu gazetowego (nadążającego $\mathrm{z}$ drukiem nut przebojów aktualnych $\mathrm{w}$ eterze), tymczasem jego piosenki zdobiły ciekawe okładki projektowane przez znamienitych grafików i rysowników zatrudnianych między innymi przez Polskie Wydawnictwo Muzyczne (W. Skulicz, J. Bruchnalski, A. Darowski, A. Kowalski, K. Wojtanowicz, J. Kurkiewicz). Zestawienie druków pozwoliło wyłonić praktyki wydawnicze o znamionach tendencji, jak tworzenie serii wydawniczej lub zbioru o cechach kolekcjonerskich, dostrzec przemiany estetyczne u różnych wydawców i w kolejnych okresach (w sposobie ilustrowania nut przeznaczonych dla dzieci i młodzieży), migrację nowoczesnych motywów graficznych obecnych w okładkach nut innych gatunków muzycznych (muzyka sonorystyczna) do druków z muzyką popularną.

Słowa-klucze: okładki muzyki popularnej, oprawa graficzna nut piosenek, W. Szpilman, A. Darowski, A. Darkow, J. Bruchnalski, W. Skulicz, A. Kowalski, Wydawnictwo Muzyczne Arcta, Nowa Scena, E. Kuthan, Czytelnik, PWM, Synkopa, Wydawnictwo Muzyczne Agencji Autorskiej, wydawnictwo Ton, przemiany w projektowaniu okładek 
Kolekcja piosenek Władysława Szpilmana, odnośnie do której dysponujemy źródłami w postaci druków muzycznych, to liczący setki tytułów zróżnicowany zbiór. Kompozytor tworzył w gatunku piosenki popularnej łatwo, ciekawie i obficie, zapisał się więc w pamięci muzycznej pokoleń między innymi właśnie dzięki przebojom (w tym utworom doby socrealizmu), choć pisał i muzykę autonomiczną, a jako pianista uprawiał z największym zamiłowaniem twórczość klasyczną i kameralistykę. Jego piosenki obejmują typy zróżnicowane tematycznie i gatunkowo: rozrywkowe, kabaretowe, filmowe, teatralne, pieśni rewiowe i masowe oraz dziecięce. Powstawały przez niemal półwiecze, od wczesnych lat trzydziestych XX wieku. Najwcześniejsze utwory o charakterze lekkim - z czasu pianistyczno-kompozytorskich studiów artysty w Berlinie w latach 1931-1932 — nie mają źródeł drukowanych ${ }^{1}$, pisane były w ramach młodzieńczej działalności zarobkowej ${ }^{2}$. Następnie ukazywały się regularnie w formie fonograficznej i w wydawnictwach nutowych prywatnych oficyn wydawniczych. Pierwotne inspiracje ich powstania łączyły się zarówno z rozwojem gatunku piosenkarskiego i zapotrzebowaniem na repertuar rozrywkowy w okresie przedwojennym (związanym z rozkwitem fonografii, radiofonii, kinematografii, powstawaniem licznych kabaretów oraz teatrów rewiowych), jak i z tużpowojennym, restytuującym szczupły i rozproszony sektor muzyczny. Późniejsze wydania związane są z działalnością radiową, zawiłymi losami polityki kulturalnej komunistycznej władzy (propagującej dostęp do kultury wśród szerokich mas społecznych, nadzorującej i określającej rodzaje twórczości) oraz z zamówieniami państwowymi, konkursami, rozwojem festiwali czy wreszcie coraz bardziej niezależnym rynkiem muzyki rozrywkowej.

Graficzny charakter druków muzycznych towarzyszących utworom Szpilmana jest równie różnorodny jak ich problematyka muzyczna ${ }^{3}$, odmienny w ramach poszczególnych podgatunków i w odniesieniu do poprzedzających je secesyjnych wydań międzywojnia czy druków nawiązujących do art déco. Zmienia się wraz z przemianami polityczno-społecznymi i stylami grafików następujących dekad, ujawniając ciekawe aspekty problematyki graficzno-ilustratorskiej: formy zdobnictwa, rodzaj reprezentacji na ilustracjach, adresata projektów okładek. Zdradza także polityczno-rynkowe meandry sceny wydawnictw muzycznych. Sam kom-

${ }^{1}$ Nieopublikowane szlagiery z czasów studenckich zachowały się w pamięci kolegi z berlińskiego okresu studiów Szpilmana - wybitnego skrzypka Henryka Szerynga, co pianista wspomina następująco: „Henryk debiutował jak 12-letni chłopiec koncertem Brahmsa w Warszawie w 1933 roku, a w kilka dni później wystąpiliśmy z wieczorem sonat w Krakowie. Gdy 40 lat później, po wykonaniu trzech koncertów Bacha, Brahmsa i Beethovena w Filharmonii Narodowej gratulowałem Szeryngowi, on usiadł do fortepianu i... zagrał mi moje pisane jeszcze w Berlinie piosenki. Taką miał pamięć muzyczną”. Por. W. Szpilman, Moje życie (zanotował Z. Zapert), „Ekspress” 8.04.1988, s. 7.

2 Pisanie piosenek miało zapewnić pianiście utrzymanie w Berlinie, ale tak się nie stało, ponieważ uznano je za konkurencyjne dla rodzimego rynku i szybko ukrócono tę działalność.

${ }^{3}$ Głębszą analizę repertuaru piosenkarskiego podejmuję w tekście Pieśni masowe Władysława Szpilmana w kontekście dorobku piosenkarskiego kompozytora, „Res Facta Nova” 2020, nr 21. 
pozytor $\mathrm{w}$ roli redaktora radiowego i popularyzatora zaangażowany był $\mathrm{w}$ proces upowszechniania repertuaru lekkiego okresu PRL i sekundował projektowi powołania specjalnego wydawnictwa poświęconego muzyce popularnej. Czy aspiracje wydawców podążały za tego typu inicjatywami, czy różniły się w ramach poszczególnych oficyn i z jakimi problemami mierzyli się popularyzatorzy, producenci i projektanci? Przegląd druków różnych typów piosenek w układzie chronologicznym częściowo odpowiada na te pytania. Pozwala też dostrzec niektóre praktyki wydawnicze i wobec wydawnictw związane z popularyzacją i charakterem repertuaru piosenkarskiego w ciągu kilku zróżnicowanych politycznie dekad - a więc i to, czego nie widać w drukach lub co znika $\mathrm{z}$ ich milieu: redukcję oficyn niepaństwowych i pomijanie wybranej motywiki w ilustracjach do muzyki okresu socrealizmu.

\section{1. „Nowa Scena wydaje tylko przeboje”}

Pierwsze wydane piosenki Szpilmana ukazały się w drugiej połowie lat trzydziestych i popularyzowały głównie utwory skomponowane na zamówienia filmu i kabaretu. Jedna z prosperujących wówczas firm fonograficznych - Syrena Record ${ }^{4}$ - wydaje na płytach filmowe numery taneczne Szpilmana, na przykład fokstrot pt. Zatańcz z nami - sł. Jerry ${ }^{5}$ (Syrena Electro $8706^{6}$ ) czy tango pt. Do ciebie phynie melodia ta ${ }^{7}$ - sł. E. Schlechter ${ }^{8}$ (Syrena Electro 9708). W skład firmy fonograficznej wchodziło od roku 1933 także wydawnictwo nutowe Nowa

${ }^{4}$ Syrena Record była przed wojną jedną z najsławniejszych wytwórni fonograficznych. Jak wskazuje Tomasz Lerski, wydała blisko 30 tysięcy utworów, w tym większość piosenek. Por. idem, Rola radia, filmu i fonografii w popularyzowaniu polskiej piosenki $w$ dwudziestoleciu międzywojennym, „Piosenka” 2014, nr 2, s. 123.

5 Jerzy Ryba (1909-1941) — scenarzysta i recenzent filmowy, autor tekstów do piosenek, które od 1930 roku podpisywał pseudonimem Jerry. Od października 1940 przebywał w getcie warszawskim, pisał teksty do „Żywego Dziennika” i dla teatru Femina. Dalsze jego losy pozostają nieznane.

${ }^{6}$ Numer płyty podaję za Tomaszem Lerskim, por. Encyklopedia kultury polskiej XX wieku. Muzyka - teatr - film, t. 1. Muzyka mechaniczna — pierwsze czterdziestolecie, Warszawa 2007, dodatek: s. X.

7 Ibidem, s. XI. Nagranie w wykonaniu Mieczysława Fogga i orkiestry Syrena Record pod dyr. Henryka Golda, https://staremelodie.pl/piosenka/2672/Do_ciebie_plynie_melodia_ta (dostęp: grudzień 2020).

${ }^{8}$ Emanuel Schlechter (1904-1943) — pseud. Olgierd Lech, twórca tekstów piosenek, scenarzysta, librecista, wokalista i kompozytor, a także reżyser i aktor, satyryk, tłumacz. W 1933 roku napisał scenariusz i teksty piosenek do pierwszego polskiego filmu z pełną ścieżką dźwiękową Każdemu wolno kochać w reż. Mieczysława Krawicza. Nagrywał z orkiestrami firmowymi wytwórni Columbia i Odeon, był kierownikiem literackim obu wytwórni. Od 1934 roku współpracował z teatrami i tworzył liczne scenariusze filmowe. Członek zarządu Związku Autorów i Kompozytorów Scenicznych. Po wybuchu wojny przebywał we Lwowie, tam zginął, prawdopodobnie w getcie lub obozie pracy. 
Scena, które jednocześnie z wydaniem wersji fonograficznej podejmuje publikowanie drukiem piosenek nagrywanych na płytach Syreny Record ${ }^{9}$. Wydawnictwo i skład główny Nowej Sceny mieściły się w Warszawie przy ulicy Nowy Świat 26, oferowało nuty utworów pod znamiennym hasłem firmy „Nowa Scena wydaje tylko przeboje" w numerowanej serii lub opatrzone angielskimi tytułami. Siedziba wydawnictwa była swoistą giełdą artystyczną, odwiedzaną przez twórców i dyrektorów teatrów; firma prowadziła także biuro teatralne, przygotowujące zespoły artystyczne do produkcji teatralnych i kinowych ${ }^{10}$.

W numerowanej edycji zeszytów nutowych Nowej Sceny ukazuje się między innymi jeden z hitów Szpilmana do słów Emmanuela Schlechtera tango pt. Szukam Ciebie... /Noca/ (il. 1).

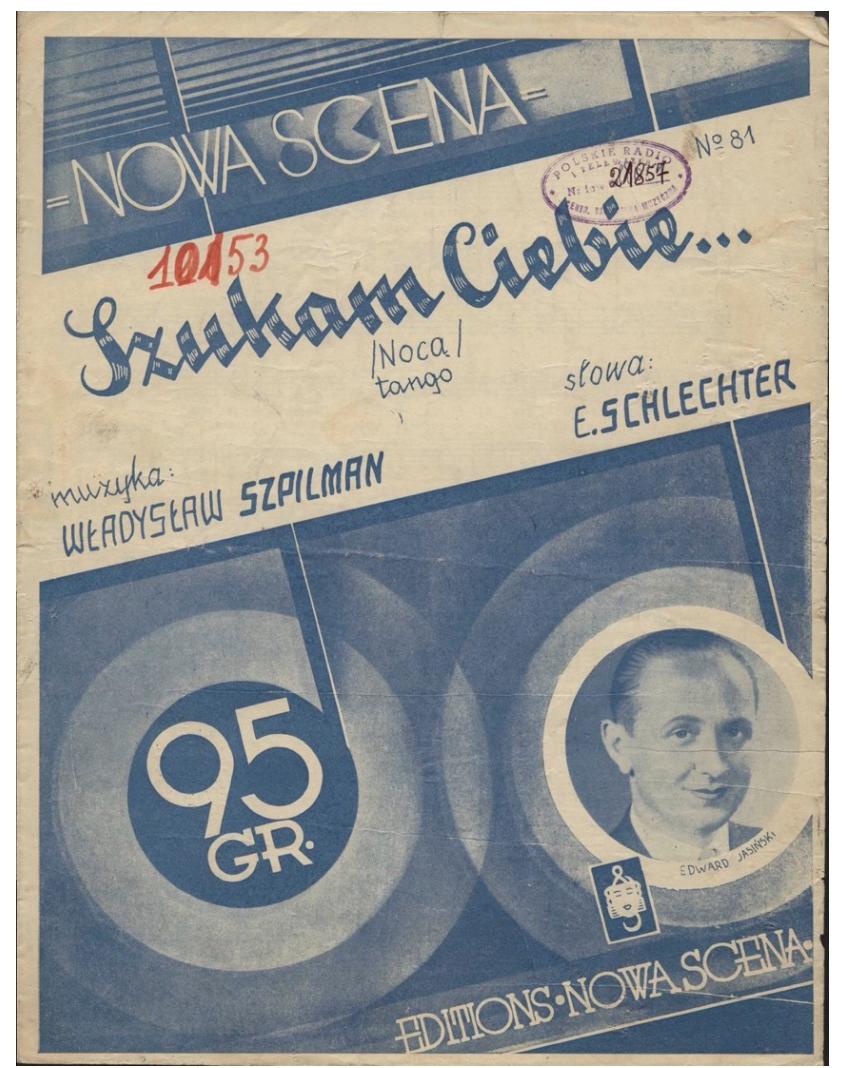

Ilustracja 1. Awers okładki nut, nr 81: tango Szukam Ciebie... /Noca/, muz. W. Szpilman, sł. E. Schlechter, wyd. Nowa Scena, Warszawa 1936

Źródło: skan, dzięki uprzejmości Nutoteki Polskiego Radia.

9 Szafa grająca. Żydowskie stulecie na szelaku i winylu. Historie z Polski, red. T. Sztyma, M. Prokopowicz, Warszawa 2017, s. 69.

10 T. Lerski, Syrena Record - pierwsza polska wytwórnia fonograficzna. Poland's first recording company 1904-1944, New York-Warszawa 2004. 
Forma graficzna druków nosi cechy nowoczesnej serii o ciekawej formule. Okładka podzielona jest na trzy strefy, w których odpowiednio rozmieszczono tytularia ${ }^{11}$ : tytuły wraz z nazwiskami autorów prezentowane są w wyszczególnionym białym tłem horyzontalnym pasie części środkowej, elementy ilustracyjne i informacyjne - w części górnej i dolnej. Muzyczny charakter druków zasygnalizowany jest użyciem znaków nawiązujących do pięciolinii i nut. „Liniatura” spacjowana jest kaskadowo w górnej części okładki, gdzie wkomponowano nazwę wydawnictwa. Tu zawieszone są także belki nut, których główki odnajdujemy niżej, pod białym pasem tytułu rozdzielającym jednokolorową przestrzeń grafiki. Główki nut ujęte są dekoracyjnie w formie okalających je koncentrycznych kręgów (sugerujących jednocześnie formę płyty winylowej) i wypełnione zdjęciami odpowiednich dla danej piosenki wokalistów oraz ceną nut $(95 \mathrm{gr})^{12}$.

W numerze $81 \mathrm{z}$ piosenką Szpilmana błękitną okładkę zdobi fotografia twarzy Edwarda Jasińskiego ${ }^{13}$ (popularyzującego piosenkę w wersji fonograficznej) umieszczona w kręgu prawej nuty. Okładkę zeszytu nieco zdynamizowano: środkowy pas informacyjny przecina ją po skosie. Do edycji tytułu, autorów i nazwy wydawnictwa użyto zróżnicowanych czcionek — od nowoczesnych, opatrzonych światłocieniem (w prezentowanej w górnej części nazwie wydawnictwa), po stylizowaną na kaligrafię typu gotyckiego (w tytule). Logotyp wydawnictwa, w formie łączącej wizerunek twarzy i klucz wiolinowy, jest widoczny w dolnej części (nad prezentowaną po raz kolejny nazwą wydawcy). Zgodnie z założeniem, by utwory popularyzować jednocześnie $\mathrm{w}$ formie nagrania i nut, wewnętrzna część druku — między dwiema stronami nut — opatrzona jest wpisem reklamującym

11 Terminu „tytularia” używam za J. Górskim, który określa go jako poręczny i popularny jeszcze pośród drukarzy i grafików w latach siedemdziesiątych XX wieku i przypomina jego definicję według Filipa Trzaski: ,zespół napisów (danych) koniecznych do zidentyfikowania danego wydania", takich jak autorstwo, tytuł, podtytuł, numer tomu, adres wydawniczy, nazwa serii itp. Por. J. Górski, Dostownie. Liternicze i typograficzne okładki polskich książek 1944-2019, Kraków 2019, s. 6.

12 Kilka pełnych numerów z serii Nowej Sceny z lat 1935-1937 ze wspomnianą okładką (na przykład 1935, nr 42: Piękne rumunki foxtrot - muz. Z. Białostocki, sł. A. Włast; 1936, nr 66: Klementyna foxtrot - muz. A. Gold, sł. I. Kranowski) dostępnych jest w zdigitalizwoanych zbiorach Polona; zob. https://polona.pl/item/klementyna-foxtrot,Njc5NzcxMjA/0/;

https://polona.pl/item/piekne-rumunki-foxtrot,ODY3NjUzMjc/0/;

https://polona.pl/item/chodzmy-felek-na-kufelek-let-s-have-one-tango-andrusowskie,NzM5MDcx NzM/ (dostęp: lipiec 2021).

13 Edward Jasiński (1912-1990) — piosenkarz, solowe występy rozpoczął w 1933 roku, następnie został statystą w Polskim Radiu, w 1937 założył Trójkę Radiową - zespół rewelersów. Pod koniec 1937 roku dokonał pierwszych nagrań dla wytwórni Odeon. Na początku 1938 roku został zaangażowany przez Syrenę Record. W okresie okupacji hitlerowskiej wraz z Czwórką Radiową występował w warszawskich kawiarniach. Powstanie w 1944 roku przeżył w Warszawie. Od listopada 1945 roku śpiewał ponownie w Polskim Radiu. Występował z orkiestrą radiową Jana Cajmera oraz jako solista z Sekstetem Polskiego Radia pod dyrekcją Stefana Rachonia. W 1947 roku wyemigrował na stałe do USA. 
dostępną wersję fonograficzną: NAGRANE NA PŁYTACH / SYRENA ELECTRO / JEDYNIE UDOSKONALONYCH.

„Wirujące” okręgi i ukośnie elementy kompozycji nadają drukom Nowej Sceny modny i zdynamizowany charakter. Okładki pozostają dwubarwne (było to częste w tym okresie) i niezmienne w ramach serii, kolejne numery wyróżniają się jednak za sprawą wizerunków różnych wykonawców/kompozytorów przeboju, przyciągając uwagę melomanów śledzących nowości wydawnicze.

\section{2.„Każdy utwór Wydawnictwa TON... przebojem!”}

Filmowe szlagiery kompozytora z tego okresu ukazują się także w wydawnictwie Ton, mieszczącym się (lub drukującym) przy ulicy Królewskiej 27 w Warszawie. Publikuje ono między innymi fokstrot Łut szczęścia z filmu w reżyserii Juliusza Gardana pt. Doktor Murek (1939) z muzyką Szpilmana. Projekt J. Konarzewskiego na druku z roku 1939 wyróżnia gazetowa kolażowa faktura z głównym elementem fotograficznym. Tło - kratkowane na wzór kartki zeszytowej - wypełniają fotosy głównych bohaterów filmowej ekranizacji: wizerunki odtwórcy głównej roli Franciszka Brodniewicza (prostokątne zdjęcie) i innych aktorów, umieszczone w nieforemnej plamie kadru filmowego (scena dansingowa). Górną i dolną część okładki zdobią wyraźnie oddzielające się od kratkowanego tła czarne pasy z tytułami w ozdobnie zaprojektowanej majuskule; mniejszą, nieozdobną, czcionką zaznaczono informacje na temat autorów (nazwisko kompozytora w wersji Spielman, autor słów piosenki pod pseudonimem Jerry) i producentów dzieł (il. 2).

Rewers okładki zapowiadający kolejne, będące w druku, piosenki (na przykład slow-fox z tego samego filmu z muzyką Szpilmana Kochać, to nie grzech), informuje o ważnym dla produkcji muzycznych procesie popularyzacji piosenek w wersjach fonograficznych (oba warianty - drukowany i płytowy — ukazują się w podobnym czasie): ,wszystkie powyższe utwory nagrane są na płytach gramofonowych"; prezentuje także charakterystyczny slogan — „Każdy utwór Wydawnictwa TON... przebojem!".

Okładka druku, podobnie jak w poprzedniej oficynie, stawia więc na aktualność (prezentując fotosy gwiazd filmowych, promując ekranizację i wydania fonograficzne), operuje kolażowo-fotomontażową konstrukcją w skromnej, czarno-białej, szacie. 


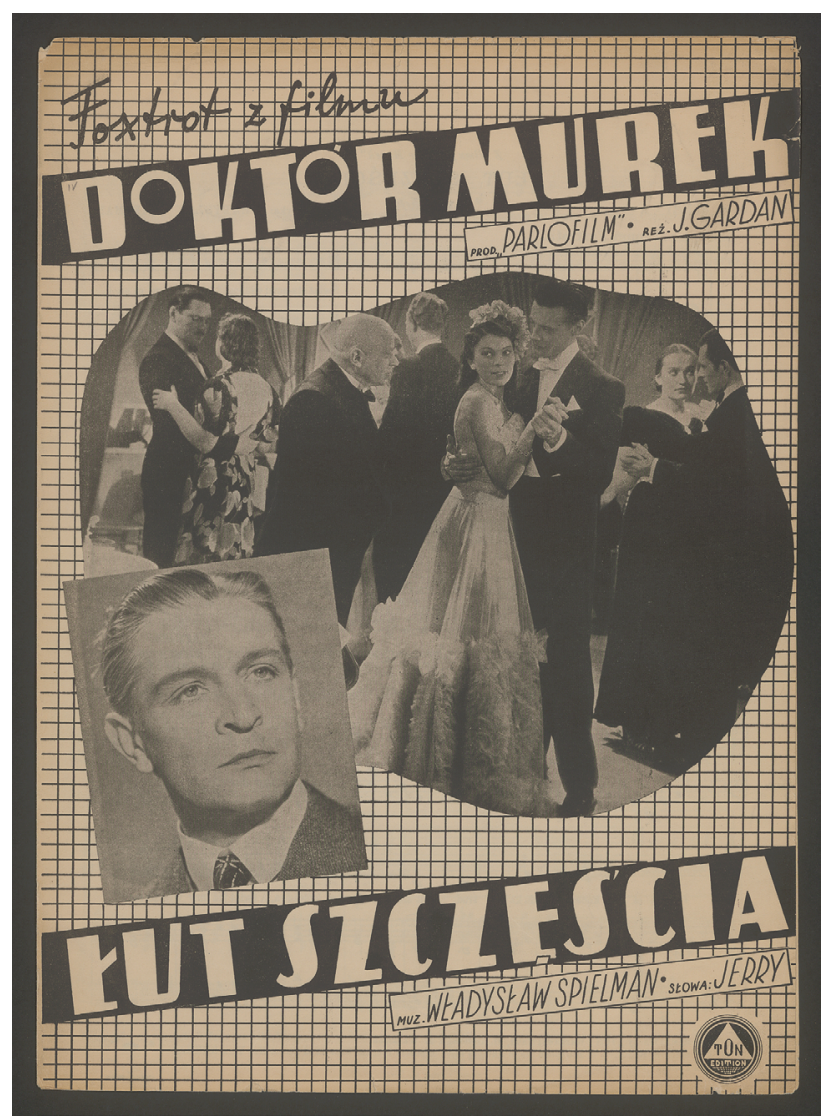

Ilustracja 2. Awers okładki fokstrota pt. Łut szczęścia z filmu Doktor Murek, muz. W. Szpilman, sł. Jerry, wyd. Ton, Warszawa 1939

Źródło: skan, dzięki uprzejmości Biblioteki Jagiellońskiej (Zbiory Muzyczne).

\section{3. "W wydawnictwach M. ARCTA ukazują się najwspanialsze przeboje"}

Innym wydawcą piosenek Szpilmana tego okresu jest uznana oficyna rodziny Arctów (założyciela Stanisława, następnie jego bratanka Michała, kontynuowana przez kolejnych spadkobierców) ${ }^{14}$. Wydawca o ugruntowanej przedwojennej

14 Założycielem firmy w Lublinie w 1836 roku był Stanisław. Od 1881 właścicielem księgarni zostaje jego bratanek Michał, po którego śmierci w 1916 roku firma przyjmuje nazwę „Spadkobiercy Michała Arcta". Michał Arct rozpoczyna warszawską działalność, a jego synowie Zygmunt, Stanisław, Jan rozszerzyli ją, tworząc filie w Lublinie, Łodzi, Poznaniu, Wilnie, Krakowie i Lwowie. W 1922 roku przekształcili ją w spółkę akcyjną, która po wojnie została podzielona na filie 
marce, znany z publikacji słownikowych i encyklopedycznych, językowych, popularnonaukowych, literatury pięknej, podręczników i książek dla dzieci, istnieje na rynku wydawniczym (w roli producenta) od 1855 roku i poświęca swą uwagę także muzyce. W XIX wieku poza monografiami muzycznymi drukuje około 100 utworów rocznie - głównie muzyki fortepianowej, prezentowanej w seriach ${ }^{15}$. Po śmierci Michała Arcta produkcje muzyczne odradzają się około 1926 roku właśnie za sprawą wprowadzenia do obrotu muzyki rozrywkowej i tanecznej, popularyzowanej pod hasłem „W wydawnictwie M. Arcta ukazują się najwspanialsze przeboje".

W roku 1936 wydawnictwo Arcta publikuje tango Szpilmana Jeśli kochasz się $w$ dziewczynie (sł. E. Schlechter) ze sztuki Kot $w$ worku ${ }^{16}$, wystawionej w Cyruliku Warszawskim ${ }^{17}$, które ukazuje się jedocześnie w tym samym roku w wykonaniu Mieczysława Fogga i orkiestry Syrena Record ${ }^{18}$.

Oprawa graficzna druku sprowadza się do ujęcia w prostą bordiurę tytulariów: wyróżnionego wersalikami tytułu w języku polskim (druk wytłuszczony) i angielskim ${ }^{19}$, mniejszą czcionką — autorów muzyki, słów i aranżacji oraz czytelnego logo wydawnictwa wraz z adresem. Awers okładki opatrzony jest ponadto pieczęcią nakłaniającą do zgłaszania utworów przez kapelmistrzów w ramach promowanego programu muzycznego („Do panów Kapelmistrzów!!! Uprzejmie prosimy o umieszczanie tych utworów w programach" ${ }^{20}$. W tej samej konwencji

wrocławską i warszawską. Filia wrocławska została zlikwidowana w 1949 roku (ze względu na niemożność opłacenia niepomiernie wysokich podatków). Wydawnictwo warszawskie kontynuowało wątłą działalność wydawniczą do 1950 roku, kiedy wcielono ją do sieci „Domu Książki” i wykreślono z rejestru handlowego. Okres likwidacyjny zakończono w 1959 roku. Za: A. Sitarz, W cieniu Polskiego Wydawnictwa Muzycznego. O kilku polskich wydawnictwach prywatnych dziatających $w$ dziedzinie muzyki po II wojnie światowej do początku lat pięćdziesiątych, [w:] Muzykolog wobec świadectw źródlowych i dokumentów. Księga pamiątkowa dedykowana profesorowi Piotrowi Poźniakowi w 70. rocznicę urodzin, red. Z. Dobrzańska-Fabiańska, Kraków 2009, s. 341-345; A. Boruc, Michat Arct. Dylematy warszawskiego ksiegarza-wydawcy schyłku XIX wieku, „Sztuka Edycji” 2013, nr 4, s. 39-40.

15 A. Sitarz, op. cit., s. 337.

${ }^{16}$ Kot $w$ worku - reż. Fryderyk Járosy, premiera 7 maja 1936, Cyrulik Warszawski, za: L. Sempoliński, Wielcy artyści małych scen, Warszawa 1968, s. 494.

17 Teatr Cyrulik Warszawski założył Fryderyk Járosy; realizował repertuar o charakterze pogodnej satyry obyczajowej i politycznej, wprowadził także pełnospektaklowe komedie muzyczne, przeplatane programami składankowymi. Teatr zakończył swą działalność w kwietniu 1939 roku. Por. S. Marczak-Oborski, Teatr w Polsce 1918-1939: wielkie ośrodki, Warszawa 1984, s. 237.

$18 \mathrm{Za:}$ https://staremelodie.pl/piosenka/69/Kiedy_kochasz_sie_w_dziewczynie (dostęp: 4.04.2019).

19 Jak pisze Sitarz, op. cit., s. 343, pozyskanie nowego rynku zbytu wśród Polonii amerykańskiej było elementem mającym pomóc w odrodzeniu muzycznej gałęzi wydawniczej.

20 Druk piosenki Szpilmana pt. Jeśli kochasz się w dziewczynie dostępny jest w kolekcji Cyfrowej Biblioteki Polskiej Piosenki (dalej: CBPP), https://bibliotekapiosenki.pl/publikacje/Szpilman Wladyslaw_Al_Legro_Jesli_kochasz_sie_w_dziewczynie_tango_z_komedii_muzycznej_Kot_w_ worku (dostęp: lipiec 2021). Do zasobów CBPP odwoływać się będę w dalszej części tekstu w celu zilustrowania wielu pozostałych omawianych w tekście projektów graficznych. 
wydawnictwo M. Arcta publikuje kolejne piosenki Szpilmana pochodzące z filmu Wrzos $(1938)^{21}$ w reżyserii J. Gardana i z muzyką kompozytora: Nie ma szczęścia bez miłości ${ }^{22}$ i Straciłam serce twe (sł. H. Herold) ${ }^{23}$. Oba druki obejmują aranżacje Jerzego Gerta na zespół taneczny ${ }^{24}$, a logo firmowe ukazuje się w związku z tym także na kartach nutowych poszczególnych głosów.

Bordiury oraz napisy na tego typu nutach były drukowane zazwyczaj w jednym kolorze (zielony, niebieski/granatowy, czarny) i był to jedyny akcent zdobniczy publikacji. Arct wydaje jednak także indywidualne wersje okładek, urozmaicone graficznie i kolorystycznie. W 1938 roku publikuje Dwa przeboje z filmu „Wrzos”, opatrzone okładką z ilustracją nawiązującą do tytułu filmu. Litografia H. Imielskiego (sztych wykonany przez Józefa Rynczaka) z sygnaturą „Kotkow” ma formę rozlewającego się na całym awersie okładki fioletowo-zielonego wrzosowiska, z którego wyodrębnia się duży tytuł filmu (opracowany w specyficznej — ,animowanej” czcionce o naprzemiennych kolorach) i piosenek (w formie pisma odręcznego w kolorze zielonym). Nazwiska twórców podano w różu, po skosie, z zastosowaniem liter zaprojektowanych w wersalikach ${ }^{25}$.

Okładki z użyciem jednego koloru, opatrzone plakatową ilustracją, są częstą formą po drugiej wojnie światowej, wówczas wydawnictwo zmienia także logo (rezygnując z litery M). Pod koniec lat czterdziestych oficyna wydawnicza Arcta publikuje w takiej konwencji autonomiczne piosenki Szpilmana. Przedstawione w manierze rysunkowo-plakatowej, opatrzone są zwykle grafiką rozpostartą na całym awersie okładki, nawiązującą do treści słów piosenki lub jej tytułu. Przykładami tego typu ujęć graficznych są druki piosenek, często według projektu Marii Bilińskiej (sztychy Józefa Rynczaka) lub Kazimierza Winklera: Parę butów mam $(1947)^{26}$, Nasz film (cop. 1947) ${ }^{27}$, Duży Jan (cop. 1947) ${ }^{28}$, Znalaztem Cię (1947) ${ }^{29}$,

21 Wrzos - melodramat, adaptacja powieści Marii Rodziewiczówny w reż. Juliusz Gardana. Premiera 16 kwietnia 1938 roku w Capitolu, w Warszawie.

22 Zob. https://bibliotekapiosenki.pl/publikacje/Szpilman_Wladyslaw_Nie_ma_szczescia_bez_ milosci_tango_z_filmu_Wrzos (dostęp: lipiec 2021).

23 Zob. https://bibliotekapiosenki.pl/publikacje/Szpilman_Wladyslaw_Stracilam_twe_serce_walc angielski_z_filmu_Wrzos (dostęp: lipiec 2021).

${ }^{24}$ Piosenka Stracilam serce twe w opracowaniu J. Gerta na orkiestrę taneczną przeznaczona była na obsadę obejmującą potrójne skrzypce, fortepian, grupę instrumentów dętych (po dwa saksofony altowe, tenorowe, trąbki i puzon), gitarę, kontrabas.

${ }^{25}$ Druk zawierający „dwie piosenki z filmu Wrzos” wyd. M. Arcta dostępny jest w Akademii Teatralnej (Warszawa), sygn. N. 1222.

26 Zob. https://bibliotekapiosenki.pl/publikacje/Szpilman_Wladyslaw_Al_Legro_Pare_butow_ mam fox-trot (dostęp: lipiec 2021).

$2 \overline{7}$ Zob. https://bibliotekapiosenki.pl/publikacje/Szpilman_Wladyslaw_Al_Legro_Nasz_film_ slowfox (dostęp: lipiec 2021).

28 Zob. https://bibliotekapiosenki.pl/publikacje/Szpilman_Wladyslaw_Al_Legro_Duzy_Jan_ slow-fox (dostęp: lipiec 2021).

29 Zob. https://bibliotekapiosenki.pl/publikacje/Szpilman_Wladyslaw_Al_Legro_Znalazlem_ cie_tango_wyd_3 (dostęp: lipiec 2021). 
Mówmy sobie ty (cop. 1949) ${ }^{30}$ - dedykowane przyszłej żonie kompozytora Halinie Grzecznarowskiej. Na okładce ostatniej z wymienionych piosenek widnieje także indywidualna sygnatura Kazimierza Winklera (dolny lewy brzeg awersu) ${ }^{31}$.

Do elementów zdobniczych należy liternictwo okładek. Nierzadko informacje o osobie śpiewaka (zespołu), którego wykonanie przydało piosence przebojowego rysu, podaje się z zastosowaniem oryginalnego, wyróżniającego się kroju liter (na przykład „Wielki sukces Jana Czerneckiego w Polskim Radiu” — w piosence Znalaztem Cię czy „Wielki przebój chóru Czejanda” — w Mówmy sobie ty) (il. 3).

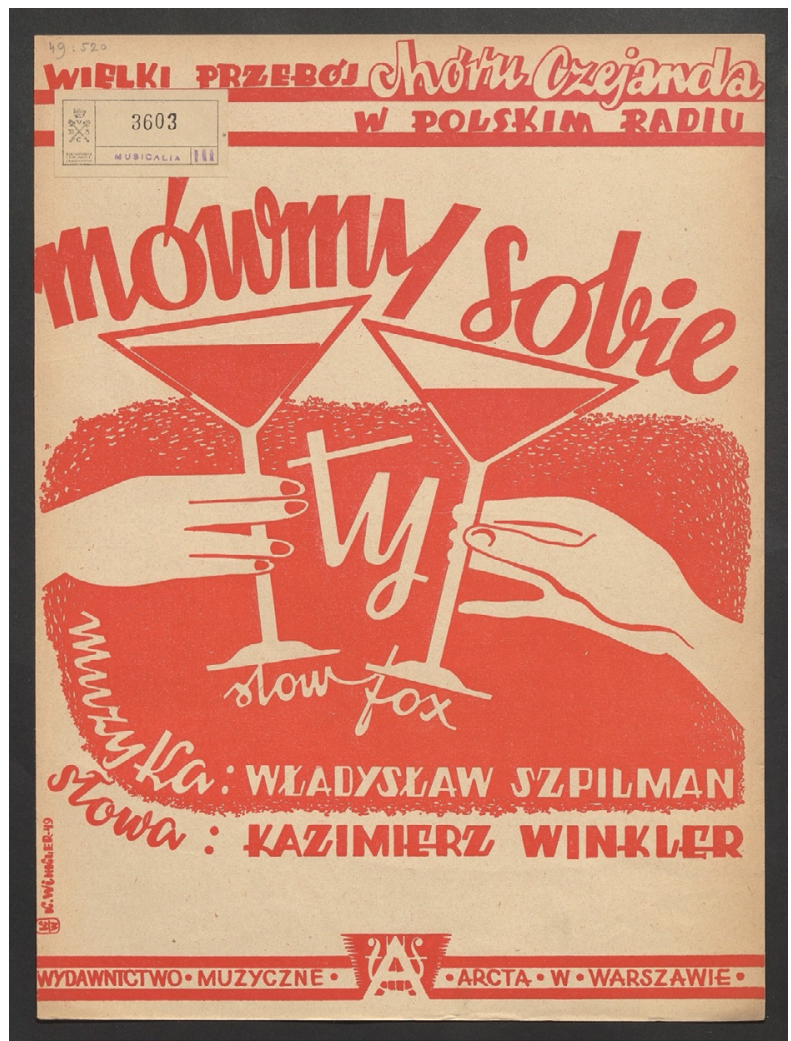

Ilustracja 3. Awers okładki druku slow-foxa pt. Mówmy sobie ty, muz. W. Szpilman, sł. K. Winkler, Wydawnictwo Muzyczne Arcta w Warszawie (cop. 1949)

Źródło: skan, dzięki uprzejmości Biblioteki Jagiellońskiej (Zbiory Muzyczne).

30 Zob. https://bibliotekapiosenki.pl/publikacje/Szpilman_Wladyslaw_Al_Legro_Mowmy_so bie_ty_slowfox_wilki_przeboj_Choru_Czejanda_w_Polskim_Radiu (dostęp: lipiec 2021).

31 Sygnatura przedstawia okolone owalem $\overline{\mathrm{i}}$ ustawione nad sobą inicjały $\mathrm{K} \mathrm{i} \mathrm{W}$ oraz napis „K. Winkler - 49”, wskazujący na oficjalny charakter praktyki artystyczno-wydawniczej autora. Winkler współpracował jako autor tekstów ze Szpilmanem, tworząc liczne przeboje piosenkarskie (w kolejnych latach także muzykę teatralną), ale był również rysownikiem projektującym plastyczną oprawę druków. 
Podobne charakterystyczne okładki — w formie jednokolorowej „plakatowej” ilustracji nawiązującej bezpośrednio do tytułu/treści utworu - są powszechne także w drukach piosenek wydawanych nakładem wydawnictwa Dom Muzyki Polskiej (Zabrze), w którym na przełomie lat czterdziestych i pięćdziesiątych ukazały się na przykład slow-fox Twój jasny wzrok ${ }^{32}$ do słów K. Winklera czy tango Noca (sł. E. Schlechter) ${ }^{33}$.

Okładki tego okresu oscylują więc między tradycyjną prostą literniczą kompozycją a pełnostronicową formą plakatową, zwykle jedno- lub dwubarwną, wprost odnoszącą się do tytułu utworu, mającą przyciągnąć uwagę młodego odbiorcy.

\section{4. „Jak śledź z cukrem" — warianty wydawnicze druków Wydawnictwa M. Arcta w kontekście socrealistycznych toposów}

Śledząc warianty wydawnicze i różne wersje instrumentalne jednego utworu, warto zauważyć ciekawą praktykę w wydawnictwie Arcta. Druki opatrzone prostą aluzyjną plakatową ilustracją związaną z tytułowym hasłem piosenki istniały na rynku obok wersji, do których Arct wykorzystał także sztych z ilustracją bębniarza (w ferworze gry) wraz $\mathrm{z}$ tancerzami i dyrygentem - litografię podpisaną nazwiskami M. Misiak, M. Torzewski. Wydawca stosował ową charakterystyczną okładkę z żywiołowym motywem (umieszczonym w centralnej części okładki) także w latach trzydziestych w formie seryjnej — do kompozycji o charakterze tanecznym różnych autorów.

Grafikę tę umieścił na przykład na druku slow-foxa Szpilmana Gdziekolwiek jesteś, wróć (cop. 1950) 34 — na orkiestrę ,,salonową”, wydaną w liczbie 500 egzemplarzy, którą opublikował wcześniej (w 1947 roku) w wersji na głos z fortepianem, z kolorową okładką projektu Bilińskiej ukazującą miejskie kamieniczki pośród gwiaździstej nocy (aluzja do słów piosenki). Seryjna okładka z perkusistą towarzyszy także piosence Walczyk murarski (cop. 1951) (35 $^{35}$ w wersji na orkiestrę taneczną. Utwór ten wydano jednak rok wcześniej na głos z fortepianem, z okładką (projektu Bilińskiej) o socrealistycznej wymowie, przedstawiającą ko-

32 Zob. https://bibliotekapiosenki.pl/publikacje/Szpilman_Wladyslaw_Al_Legro_Twoj_jasny_ wzrok_slow-fox (dostęp: lipiec 2021).

${ }^{33}$ Zob. https://bibliotekapiosenki.pl/publikacje/Szpilman_Wladyslaw_Al_Legro_Noca_tango_ wielki_przeboj_4_asow (dostęp: lipiec 2021).

34 Zob. https://bibliotekapiosenki.pl/publikacje/Szpilman_Wladyslaw_Al_Legro_Gdziekolwiek_ jestes_wroc_slow-fox (dostęp: lipiec 2021).

35 Zob. https://bibliotekapiosenki.pl/publikacje/Szpilman_Wladyslaw_Al_Legro_Walczyk_mu rarski (dostęp: lipiec 2021). 
bietę i mężczyznę wznoszących budowlę (czerwone cegły i rusztowania, niebieskie niebo i postaci $)^{36}$.

Socrealistyczna tematyka okładki w wersji utworu na głos z fortepianem nawiązuje do tytułowego bohatera — piosenki „murarskiej”: „wszędzie wywoła uśmiech na twarzy, z uśmiechem zawsze pracować lżej, bo to piosenka naszych murarzy, murarskie serce bije w niej" (sł. K. Winkler). Tymczasem seryjny typ okładki Walczyka zdradza jego muzyczne cechy gatunkowe (walczyk), charakter (muzyka popularna) i przeznaczenie (utwór taneczny, do wykonania przez zespoły muzyki tanecznej), które wbrew socrealistycznej symbolice pierwotnej okładki, semantycznym wątkom tekstu i propagandzie lansowania określonej tematyki pozwalają zaliczyć utwór raczej do kompozycji bliższych tradycyjnym rozrywkowym produkcjom piosenkarskim niż do „rytualnych” pieśni masowych ${ }^{37}$.

Rozdźwięk między walorami muzycznymi i warstwą tekstową — oraz, co istotne $\mathrm{w}$ tym wypadku, także obrazem - dobrze oddaje wypowiedź jednego z artystów, poruszająca tematykę innych piosenek w tym typie (na przykład Zmartwienia maszynisty):

Ciężka jest rola kompozytora, gdy dostaje on reportaż z budowy ze stosami cegieł i każe mu się podłożyć do niego melodię [...]. Czy istotnie prócz cegieł, Mariensztatu, mostów, MDMu czy traktora nic innego nie może być motywem piosenki? [...] O często zachodzącej dysharmonii między duchem melodii i tekstem świadczy taki przykład, że w udaną i przyjemną melodię Szpilmana wtłoczono motyw o maszyniście. Wybaczcie, ale to tak pasuje, jak śledź z cukrem. Jedno $\mathrm{z}$ drugim się kłóci ${ }^{38}$.

Wizualna warstwa okładek utworów na głos z fortepianem niekiedy — jak widać na przytoczonych przykładach — wzmacniała ich ideologizujące toposy, idąc $\mathrm{w}$ parze nie tyle z muzycznymi cechami utworu, ile z narzuconymi elementami semantycznymi tekstów piosenek i socrealistycznym kontekstem twórczości tego okresu. W wersjach przeznaczonych na orkiestry i zespoły taneczne, które nie celowały w indywidualnego nabywcę druku, jego grafika pozostawała neutralna, zgodna z muzycznym przeznaczeniem utworu (seria muzyki tanecznej).

36 Druk Walczyka murarskiego z okładką proj. Bilińskiej dostępny jest w Warszawskiej Akademii Teatralnej, sygn. N 1229.

37 Por. D.G. Tomkins, Composing the Party Line. Music and Politics in Early Cold War Poland and East Germany, Indiana 2013, s. 38.

38 Stenogram z narady w sprawie aktualnych problemów muzyki tanecznej i rozrywkowej w dniu 22 maja 1954 r., Archiwum Związku Kompozytorów Polskich (dalej: AZKP), sygn. 12/68, s. $17 / 4-17 / 5$. 


\section{5. "Zezwala się na drukowanie" - problematyczne aspekty procesu wydawniczego na przykładzie oficyny Eugeniusza Kuthana (Warszawa-Kraków)}

W drugiej połowie lat czterdziestych innym wydawcą piosenek Szpilmana był Eugeniusz Kuthan ${ }^{39}$ (działający przy placu Trzech Krzyży 12), który opublikował między innymi Dziewczyno do słów Romana Sadowskiego (cop. 1946, druk 1949). Elegancka okładka do tego utworu projektu Witolda Kalickiego operująca kontrastem (żółte lub białe tło versus czarna grafika) prezentuje ukośnie zakomponowaną ilustrację, wykorzystując archetypiczny motyw fortepianu i pianisty ${ }^{40}$.

Projekty opublikowane, a także te złożone do druku, lecz niezrealizowane przez wydawnictwo odsłaniają niełatwe meandry procedury wydawniczej tego okresu. Proces publikacji podzielony był na etapy opiniodawcze kilku instytucji (w tym restrykcyjnego cenzorskiego organu — Głównego Urzędu Kontroli Prasy, Publikacji i Widowisk oraz Państwowego Instytutu Sztuki) i dotyczył, poza kwestiami merytorycznymi (zgodnymi z kierunkiem polityki), także decyzji praktycznych (na przykład dostępu do upaństwowionych drukarni); samo zaś zezwolenie na druk przydzielane było na określony datą czas, w którym wydawca musiał zrealizować zadanie (zorganizować projekty okładki, promocję itp.). Jeśli jeden z etapów nie został rozpatrzony pozytywnie, skutkowało to zakazem wydania utworu, czego ślad odnajdujemy w materiałach archiwalnych wydawcy ${ }^{41}$. Jak znajdujemy w korespondencji dotyczącej niewydanych przez E. Kuthana utworów kilku autorów, koncesję na ich druk cofnięto mimo poczynionych nakładów na opracowanie graficzne i reklamę. W wypadku utworów Szpilmana do dziś zachował się wczesny rękopiśmienny autograf nut, na których widnieje pieczęć Głównego Urzędu Kontroli Prasy, Publikacji i Widowisk z adnotacją ,zezwala się na drukowanie nr 1-93.986", a który nie został jednak wydany. Niemożność publikacji wynikała — jak thumaczył wydawca w korespondencji — w tym wypadku z decyzji władz „odmawiających przydziału papieru” ${ }^{42}$.

39 Eugeniusz Kuthan (1897-1955) — księgarz, właściciel księgarni przy pl. Trzech Krzyży 12 w Warszawie, która działała jeszcze po wojnie.

40 Zob. https://bibliotekapiosenki.pl/publikacje/Szpilman_Wladyslaw_Al_Legro_Dziewczyno_ tango_wyd_3 (dostęp: lipiec 2021).

${ }^{41}$ Por. dokumentacja archiwalna ZAIKS związana z wydawnictwem E. Kuthana.

${ }^{42}$ List z Wydawnictwa E. Kuthana do Stowarzyszenia ZAIKS z dnia 20.01.1950 roku, Archiwum ZAiKS (materiały dotyczące twórczości W. Szpilmana). 


\section{Druki Spółdzielni Wydawniczej „Czytelnik" z początku lat pięćdziesiątych}

Poczynania państwowe były bardzo represyjne wobec prywatnych oficyn wydawniczych. Do 1947 roku niepaństwowe i spółdzielcze wydawnictwa dostarczały jeszcze około połowy wszystkich egzemplarzy książek publikowanych w Polsce Ludowej ${ }^{43}$. Od lat pięćdziesiątych — na skutek działań ograniczających ich działalność i w efekcie spadku ich produkcji — ich udział w rynku wydawniczym to zaledwie $8 \%{ }^{44}$. Głównymi wydawcami pieśni i piosenek Szpilmana pozostają wówczas dwie instytucje: istniejący do 1954 roku dział muzyczny Spółdzielni Wydawniczej „Czytelnik” (Warszawa) i Państwowe Wydawnictwo Muzyczne (Kraków; dalej: PWM), które drukują zarówno popularne piosenki rozrywkowe, piosenki dziecięce, jak i skomponowane przez Szpilmana pieśni masowe okresu socrealizmu ${ }^{45}$.

W typografii okładek piosenek Szpilmana publikowanych przez oficynę Czytelnik przeważa element formalny. Wydania pieśni z lat 1950-1953 to skromne pod względem graficznym druki, które - ze względu na prostą formę winiety ramkowej okalającej tytuł i tekst pieśni (na przykład ornament florystyczny) układają się w rodzaj kolekcji. Symboliczny wzór ozdobnej ramy okładki, w którą wkomponowane jest logo wydawcy w formie liry (lub skrzyżowanych trąbek i gitary), jest nieznacznie modyfikowany w kolejnych drukach, ukazując różne wzory zdobnicze ${ }^{46}$.

Formalny rys w projektach Czytelnika widoczny jest także we wczesnych projektach okładek do pieśni masowych z elementami ilustracyjnymi. Socrealistyczne utwory (nierzadko wydawane przy okazji oficjalnych prezentacji) w swej formie graficznej nawiązują do estetyki symboli państwowych lub operują motywami ograniczonymi do jaskrawych emblematów (czerwono-białych lub wojsko-

43 W.A. Ciszewska, Źródła do badań nad dziejami książki lat 1945-1950, „Biuletyn EBIB” 2007, nr 1, http://www.ebib.p1/2007/82/a.php?ciszewska (dostęp: grudzień 2020).

44 Ibidem.

45 A. Sitarz, op. cit., s. 337, zauważa: „władze państwowe, choć początkowo pozornie przychylne inicjatywie prywatnej, starały się objąć monopol w dziedzinie polityki kulturalnej oraz środków przekazu informacji i kształtowania opinii społecznej. Ograniczały swobodę działania niepaństwowych instytucji różnymi metodami: prawnymi, administracyjnymi, nadzorem cenzorskim, reglamentacją papieru, podatkami, nierówną konkurencją, manipulowaniem prawami autorskimi”.

46 Por. ilustracje w CBPP, https://bibliotekapiosenki.pl/publikacje/Szpilman_Wladyslaw_Latar nie_warszawskie; https://bibliotekapiosenki.pl/publikacje/Szpilman_Wladyslaw_Piosenka_o_kapita nie; https://bibliotekapiosenki.pl/publikacje/Szpilman_Wladyslaw_Al_Legro_Czerwony_auto bus_fox-trot; https://bibliotekapiosenki.pl/publikacje/Szpilman_Wladyslaw_Al_Legro_Nasza_War szawo_(1953) (dostęp: lipiec 2021). 
wych barw, odniesień muzycznych symbolizowanych przez słowika) i oficjalnym (nieozdobnym) krojem liter ${ }^{47}$.

Wybrane pieśni Szpilmana wydawane w Czytelniku są opatrzone indywidualnymi okładkami, pozbawionymi oficjalnej lub winietowej formy zdobnictwa, lecz równie skromnymi w swej prostej warstwie ilustratorskiej ${ }^{48}$. Niekiedy autorskie opracowania ukazują się jednocześnie i w PWM, gdzie ujawniają konotacje ilustratorsko-semantyczne powszechnie stosowane i w innych utworach (muzycznych, literackich). Kompozycje okładek budowano często na osi z wykorzystaniem typowych motywów (na przykład marynistycznych w wypadku utworów o morskiej tematyce). Dla przykładu okładka projektu Witolda Skulicza do Morskich orłów nie akcentuje kontekstu patriotycznego pieśni (na przykład postaci tytułowych bohaterów), ilustruje ciemny kadłub statku (nocą), ukazany na niebiesko-zielonym tle ${ }^{49}$.

Utwory dla dzieci tego okresu wydawane przez Czytelnik urozmaicono niewielkich rozmiarów ilustracjami na okładce zeszytu oraz wewnątrz druku. Rysunki autorstwa Felicji Skalińskiej ${ }^{50}$ do dwóch zeszytów Piosenek dla dzieci Szpilmana, zbliżone są do klasycznych monochromatycznych ilustracji z późno dziewiętnastowiecznych pozycji dziecięcych czy botanicznych sztychów encyklopedycznych: szkicowane piórkiem i w „baśniowo-realistycznej” manierze (il. 4). Liternictwo zaprojektowano skromnie: autora muzyki zapisano płynnie wijącą się kaligrafią, tytuł wyszczególniono jedynie majuskułą, pod spodem umieszczając sygnet wydawniczy (lira) ${ }^{51}$.

Oprawy graficzne nut wydawanych przez oficynę Czytelnik charakteryzuje więc swoista powściągliwość. Istotnym elementem okładek jest czytelność informacyjna i klasyczna forma, nawiązująca do historycznych rozwiązań kompozycyjnych (bordiury) z widocznym i rozpoznawalnym (równie tradycyjnym w swej formie) sygnetem wydawnictwa oraz skromnym wykorzystaniem kolorów i technik graficznych.

47 Zob. https://bibliotekapiosenki.pl/publikacje/Szpilman_Wladyslaw_Al_Legro_Ludzie walki i pracy (dostęp: lipiec 2021).

48 Zob. https://bibliotekapiosenki.pl/publikacje/Szpilman_Wladyslaw_Deszcz (dostęp: lipiec 2021).

49 Zob. https://bibliotekapiosenki.pl/publikacje/Szpilman_Wladyslaw_Al_Legro_Morskie_orly_ (Polskie_Wydawnictwo_Muzyczne) (dostęp: lipiec 2021).

50 Felicja Skalińska (?-2013) — artystka plastyk, graficzka, współtworzyła Grupę Pracowni Litograficznej im. P. Picassa w Warszawie.

51 Zob. https://bibliotekapiosenki.pl/publikacje/Szpilman_Wladyslaw_Al_Legro_Piosenki_dla_ dzieci_Zeszyt_1; https://bibliotekapiosenki.pl/publikacje/Szpilman_Wladyslaw_Al_Legro_Piosenki_dla_dzieci_na_glos_i_fortepian_Zeszyt_2 (dostęp: lipiec 2021). 
4

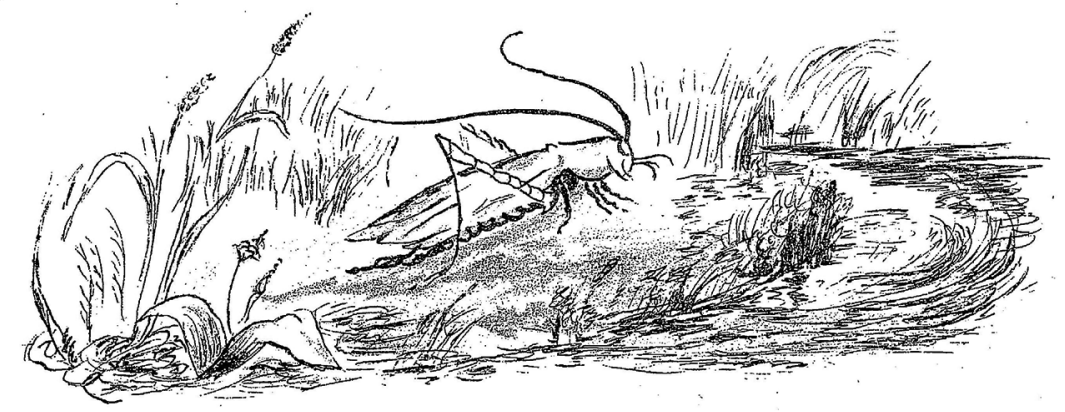

\section{Konik polny}

Stowa: HANNA JANTSZEWSKA

MUZYKka: WZADYSEAW SZPILMdN
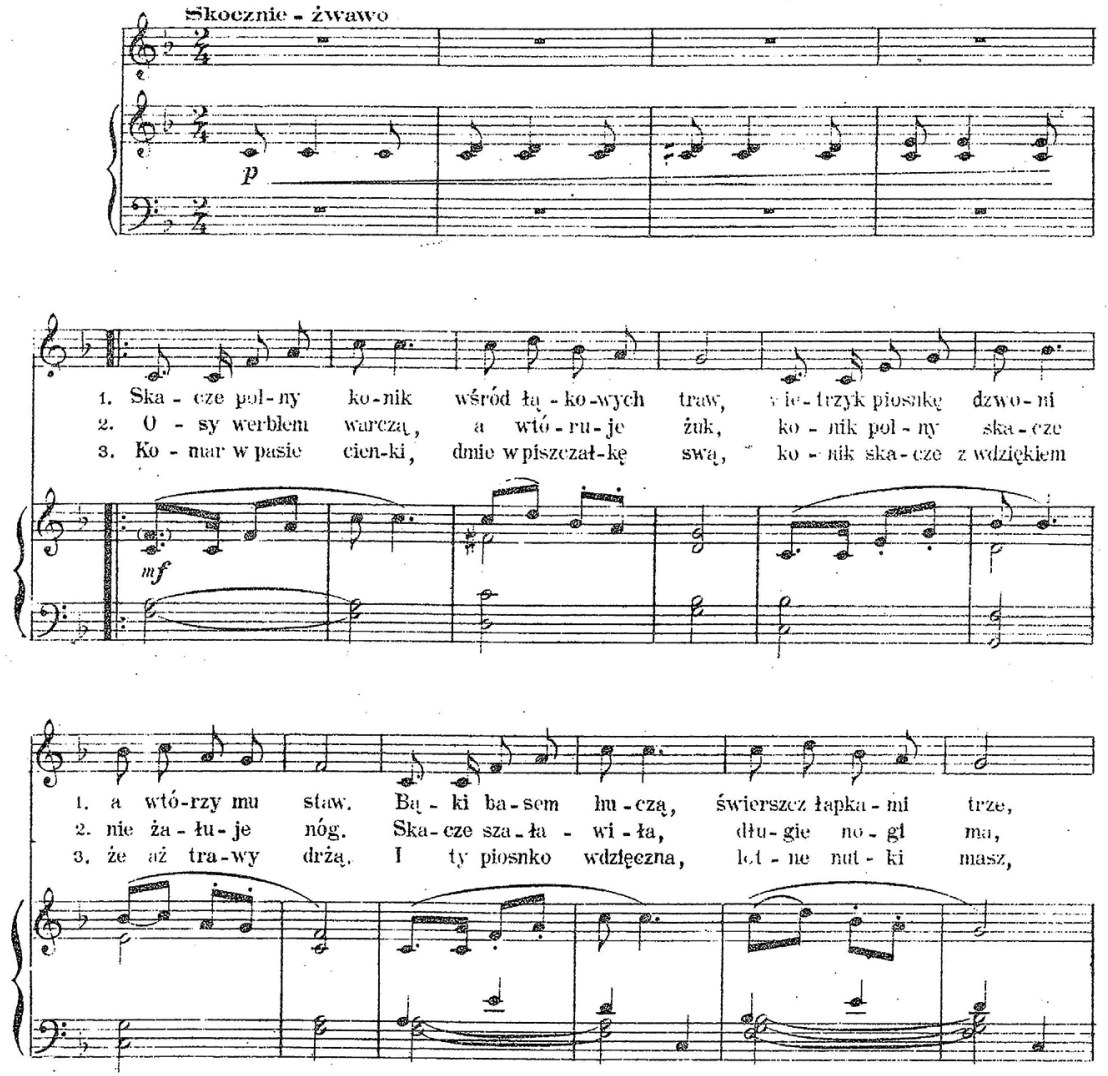

Nr. 184, ,Cyteluik"

Ilustracja 4. Rysunek Felicji Skalińskiej do piosenki pt. Konik polny z pierwszego zeszytu „Piosenek dla dzieci” W. Szpilmana, Czytelnik, Warszawa 1952

Źródło: skan, K. Staśko-Mazur, zbiory prywatne. 


\section{Serie Państwowego Wydawnictwa Muzycznego i idea wydawnictwa gazetowego}

Wśród nut zaplanowanych jako wielonumerowy zbiór repertuaru popularnego znajdują się także druki Polskiego Wydawnictwa Muzycznego wydawane pod szyldem „Biblioteka Orkiestr Tanecznych” (dalej: BOT) ${ }^{52}$ — prezentujące utwory w instrumentacji na zespół orkiestry tanecznej ${ }^{53}$ czy w serii „Biblioteka Śpiewamy i tańczymy” — w układzie na głos z fortepianem lub akordeonem. Nierzadko ten sam utwór ukazywał się w kilku edycjach, umożliwiając realizację muzyki na różne składy wykonawcze ${ }^{54}$.

W roku 1954 numery z serii „Biblioteki Orkiestr Tanecznych” charakteryzowała okładka ozdobiona szeroką jednokolorową bordiurą, wypełniona szkicowymi „rytami” instrumentów na jednolitym kolorze tła zróżnicowanym w kolejnych zeszytach. Bordiura okala umieszczone w centrum na jasnym tle tytularia, których symetryczne rozmieszczenie dopełniają wykreślone poziomo i pionowo układy linii ${ }^{55}$.

Zbiór na głos i instrument o nazwie „Biblioteka Śpiewamy i tańczymy” prezentuje natomiast numery o okładkach, które wyróżniały się umieszczeniem literniczego wzoru eksponującego nazwę serii w wertykalnym pasie wzdłuż lewej strony awersu okładek o zróżnicowanych kolorystycznie zeszytach ${ }^{56}$. W podobnej konwencji zdobniczej (ograniczonej do projektu literniczego prezentującego nazwę serii $\mathrm{w}$ wertykalnym pasie i pozostałych informacji rozmieszczonych horyzontalnie) publikowane są czarno-białe numery z serii $\mathrm{BOT}^{57} \mathrm{z}$ lat sześćdziesiątych.

52 W ramach „Biblioteki Orkiestr Tanecznych” utwory Szpilmana ukazywały się regularnie; na obsadę orkiestr tanecznych we wczesnych zeszytach opublikowano między innymi Czerwony autobus i Morskie orty (1954, nr 2), Cicha noc, Deszcz (1954, nr 3).

$53 \mathrm{~W}$ instrumentacji Edwarda Czernego był to następujący skład: saksofon I alt. (Es), II ten. (B), III alt. (Es); trąbka I, II $(B)$; puzon; gitara; akordeon; fortepian; perkusja — mały bęben, wielki bęben, talerz; skrzypce I, II, III, kontrabas (wskazany skład instrumentalny występuje w piosenkach Deszcz i Cicha noc)

54 Dla przykładu piosenka pt. Gdy się kogoś ma w 1954 roku występuje w numerze 3 serii „Śpiewamy i tańczymy” i 28 „Biblioteki Orkiestr Tanecznych”.

55 Przykłady tego typu opracowań znajdziemy w zbiorach CBPP, jak nr 28 z piosenką $G d y$ się kogoś ma i nr 56 z Piosenka nieortograficzną: https://bibliotekapiosenki.pl/publikacje/Harald_ Jerzy_Moj_chlopiec_fokstrot; https://bibliotekapiosenki.pl/publikacje/Jablonski_Henryk_Czasem_ bywa_tak_wolny_walc (dostęp: lipiec 2021).

56 Liczne numery z serii „Biblioteka Śpiewamy i tańczymy” dostępne są w CBPP: https:// bibliotekapiosenki.pl/publikacje/Szpilman_Wladyslaw_Al_Legro_Dziewczyna_i_roze_glos_z_ fortepianem; https://bibliotekapiosenki.pl/publikacje/Szpilman_Wladyslaw_Al_Legro_Dziewczeca_ piosenka_slowfox_glos_z_fortepianem_lub_akordeonem; https://bibliotekapiosenki.pl/publikacje/ Szpilman_Wladyslaw_Al_Legro_Letni_dzien_slowfox_glos_z_fortepianem_lub_akordeonem (dostęp: lipiec 2021).

57 Zob. https://bibliotekapiosenki.pl/publikacje/Szpilman_Wladyslaw_Al_Legro_Gra_kata rynka_walc (dostęp: lipiec 2021). 
Powołanie tego typu cyklicznych wydań, w formie zbliżonej do periodyków tematycznych, łączyło się z żywymi dyskusjami propagatorów i twórców muzyki rozrywkowej tego okresu nad procesem wydawniczym i problemem upowszechniania muzyki. Szpilman, który znajdował się w gronie członków i prezydium tak zwanej Komisji ds. Muzyki Rozrywkowej i Tanecznej (dalej: KMRiT ) ${ }^{58}$, istniejącej przy Związku Kompozytorów Polskich, włączał się w debaty dotyczące problemów poziomu i sposobu popularyzacji muzyki rozrywkowej. W roku 1954 prezydium KMRiT podjęło namysł nad działaniami mającymi na celu rozwinięcie ambitnego repertuaru muzyki lekkiej i formy ich druku. Podczas czerwcowych rad rozpoczęto debatę dotyczącą wydawania nut, wysunięto między innymi propozycję powołania filii PWM (z pełną samodzielnością redakcyjną i produkcyjną) poświęconej zagadnieniom muzyki rozrywkowej i tanecznej oraz popularnej ${ }^{59}$.

Szpilman zabiera głos między innymi w kwestii ,popularnych wydawnictw sezonowych" ${ }^{60}$, a gdy w połowie października Kazimierz Serocki przedstawia trudności wydawnicze (dotyczące realizacji projektów muzyki rozrywkowej i tanecznej), zarzuca PWM, że w procesie wydawania i sprzedaży utworów nie kieruje się popularnością piosenek, lecz trzyma sztywno tak zwanego planu wydawniczego (ustalanego $\mathrm{z}$ wyprzedzeniem harmonogramu publikowania określonych utworów). Jako przykład wskazuje zbyt późną sprzedaż nut wybranych piosenek, które zostały wydane dopiero wtedy, gdy przestały już być śpiewane. W tej sytuacji — zauważa kompozytor — „niezbędne jest przejście wydawnictwa muzyki rozrywkowej i tanecznej na operatywność gazetową, chociażby kosztem dbało-

58 Komisja ds. Muzyki Rozrywkowej i Tanecznej (KMRiT) działała przy Związku Kompozytorów Polskich jako ciało doradcze i opiniodawcze, mające w założeniu koordynować politykę kulturalną wszystkich instytucji w zakresie muzyki rozrywkowej i tanecznej (sprawy wydawnictw nutowych i płytowych, powołanie kolegiów repertuarowych i profesjonalnych kierownictw muzycznych w instytucjach typu teatry muzyczne, operetki itp., podnoszenie kwalifikacji zawodowych muzyków niezrzeszonych, określanie udziału muzyki rozrywkowej i tanecznej w Festiwalu Muzyki Polskiej). Jak podaje Urbański w sprawozdaniu podsumowującym pierwszy rok działalności KMRiT, nie była ona oficjalnym organem ZKP, który sam niewiele ingerował w jej prace. Według Urbańskiego akcja zamówień nie przyniosła większych rezultatów (ze względu na zniechęcające stawki), Festiwal Muzyki Polskiej dowiódł, że kompozytorzy pisali utwory zbyt trudne dla istniejących zespołów rozrywkowych, PWM zaś nie spełniło obietnicy stworzenia nowego wydawnictwa muzyki popularnej. Z pozytywnych aspektów zauważa podniesienie poziomu wykonawczego orkiestry Cajmera i stworzenie dwóch nowych zespołów jazzowych: Darmosza i Krakowskiego. Por. Protokół z posiedzenia Komisji dla spraw Muzyki Rozrywkowej i Tanecznej przy Związku Kompozytorów Polskich w dniu 5 czerwca 1954 r., s. 1, Komisja d/s Muzyki Rozrywkowej i Tanecznej. Protokoły z posiedzeń. 1954-57, AZKP, sygn. 12/69.

59 Protokół nr 2 z posiedzenia plenarnego Komisji dla Spraw Muzyki Rozrywkowej i Tanecznej przy ZKP w dniu 9 czerwca 1954 r. s. 1; Protokół nr 3 z posiedzenia plenarnego Komisji dla Spraw Muzyki Rozrywkowej i Tanecznej przy ZKP w dniu 12 czerwca 1954 r., s. 1, AZKP, sygn. 12/69.

60 Wraz z dyrektorem PWM Tadeuszem Ochlewskim postulują m.in. konieczność przeglądu kwalifikacji muzyków kawiarnianych i granego przez nich repertuaru, ibidem, s. 4. 
ści o szatę graficzną" ${ }^{61}$. Pomysł poparł zarówno Serocki, jak i naczelny redaktor PWM - Mieczysław Tomaszewski, który zgodził się na zorganizowanie wydawnictwa „gazetowego" specjalnie powołanego dla muzyki tanecznej i rozrywkowej. Jeszcze w grudniu 1954 roku złożono odpowiedni memoriał do Zarządu Głównego w sprawie nowego wydawnictwa ${ }^{62}$. W podobnym czasie za sprawą KMRiT pojawia się dwutygodnik ,Śpiewamy i tańczymy”63, wkrótce zaś seminaria kształcące muzyków w dziedzinie muzyki rozrywkowej.

Utworzenie dwutygodnika zaliczono do niewątpliwych sukcesów prac Komisji, choć drugiego - przeznaczonego dla muzyki lekkiej wydawnictwa ,gazetowego", jak wynika z protokołu sprawozdawczego z pracy KMRiT (I/1955) - nie udało się powołać $\mathrm{w}$ tym czasie ${ }^{64}$. Podczas spotkania sprawozdawczego prac KMRiT w 1955 roku Szpilman zauważa jednak pewną poprawę w praktyce upowszechnieniowej PWM: ,wydawnictwo publikuje nieraz piosenki jeszcze niespopularyzowane ani w Radio ani na płytach. Tym niemniej drugie wydawnictwo

61 Protokół nr 14 z posiedzenia plenarnego Komisji dla Spraw Muzyki Rozrywkowej i Tanecznej przy ZKP w dniu 15 października 1954 r., s. 2, AZKP, sygn. 12/69.

62 Protokół nr 17 z posiedzenia plenarnego Komisji dla Spraw Muzyki Rozrywkowej i Tanecznej przy ZKP w dniu 14.XII.1954 r., AZKP, sygn. 12/69.

63 O powołaniu dwutygodnika „Śpiewamy i tańczymy” jako rezultacie działań KMRiT wspomina W. Elektorowicz podczas debaty pierwszego plenum KMRiT w 1955 roku. Por. Protokół I plenarnego posiedzenia Komisji dla Spraw Muzyki Rozrywkowej i Tanecznej dnia 17 października 1955 r., s. 4, AZKP, sygn. 12/69. Pierwsze numery serii „Śpiewamy i tańczymy” pod red. Witolda Rudzińskiego wydano już w roku 1954, a plan na rok 1955 według Tomaszewskiego obejmował 24 numery (czyli 120 utworów) Por. Protokół nr 14, s. 4. Seria „Śpiewamy i tańczymy” jako nuty, następnie jako czasopismo, wydawana była do 1987 z różną częstotliwością (w latach 1984-87 jako dwumiesięcznik), w roku 1955 z podtytułem ,na głos z fortepianem” (od roku 1961, nr 1-151 bez podtytułu). W latach 1971-1972 część tekstową kontynuuje czasopismo „Rytmy: śpiewamy i tańczymy”. Od roku 1958 numery 11-89 opatrzone podtytułem „magazyn muzyczny”. Na przełomie lat sześćdziesiątych i siedemdziesiątych zawierają dodatki. Ostatni zeszyt z roku 1987 nosi nr 6.

64 Problem małej liczby wydawnictw rodzimego repertuaru rozrywkowego podjęto ponownie w 1957 roku, pisząc: „Komisja uważa za konieczne stworzenie oddzielnego wydawnictwa dla muzyki rozrywkowej i tanecznej" (wniosek z 26 kwietnia 1957 roku). W tym czasie potrzebę nowych wydań nutowych (rozrywkowych, tanecznych i popularnych), ,niezaspokojonych dostatecznie przez Polskie Wydawnictwo Muzyczne" przyznaje także Państwowe Przedsiębiorstwo Obrotu Księgarskiego „Dom Książki”, także w korespondencji ze spółdzielnią Znak, starającą się o koncesję na wydania nutowe (list z 17 września 1957 roku), a KMRiT zauważa, że w dziedzinie muzyki rozrywkowej istnieje miejsce dla tego typu wydawnictw (innych niż PWM i mogących wypełnić zaistniałą od lat lukę), które z radością powita i w miarę możliwości wesprze. Spółdzielcze wydawnictwo (Znak), mimo aktywnej działalności i publikacji utworów tanecznych i rozrywkowych (od 1956 roku) oraz wielokrotnych starań o przyznanie koncesji, nie zdołało jej otrzymać do roku 1958. Por. dokumenty archiwalne ZKP: Wniosek KMRiT do Zarządu Głównego Związku Kompozytorów Polskich z 26 kwietnia 1957 roku, list Państwowego Przedsiębiorstwa Obrotu Księgarskiego „Dom Książki” do Spółdzielni usługowej „Znak” z dnia 17 września 1957 r., list Usługowej Spółdzielni Pracy „Znak” do Zarządu Związku Kompozytorów Polskich z dnia 7 stycznia 1958 r., Komisja d/s Muzyki Rozrywkowej i Tanecznej. Protokoły z posiedzeń. 1954-57, AZKP, sygn. 12/69. 
powinno także powstać”65. Prośbę o jego powołanie KMRiT ponawia oficjalnie pismami jeszcze w kolejnych latach, w tym dokumentem podpisanym przez Szpilmana (jako jego przewodniczącego) i J. Wasowskiego (jako sekretarza) w 1958 roku $^{66}$. Mimo wskazań na niebezpieczne i szkodliwe skutki monopolistycznej polityki wydawniczej (eliminującej prywatne oficyny wydawnicze i różnorodność form muzycznych) i woli zaangażowania w przedsięwzięcie także ze strony niepaństwowych wydawców inicjatywa pozostała, jak się wydaje, bez skutku.

Tymczasem piosenki popularne Szpilmana publikowane w ramach serii wydawniczych PWM ukazują się do lat siedemdziesiątych w kilku wariantach graficznych. Okładki zeszytów „Śpiewamy i tańczymy: na głos z fortepianem”"67 z początku lat pięćdziesiątych podobnie jak pierwotna wersja z serii „Bibliotek” mają charakter opraw literniczo-typograficznych. Zdobią je szerokie bordiury w kolorze charakterystycznym dla danego numeru, wypełnione łukowatymi cieniami i tytułem serii zaprojektowanym $\mathrm{w}$ indywidualnym kroju liter ${ }^{68}$. W centrum okładki umieszczono tytuły piosenek danego numeru na jasnym prostokącie „wklejki” zwierciadła ${ }^{69}$. W kolejnych latach wydania pozostają wierne jednokolorowym lub dwubarwnym zeszytom z odpowiednio przeformułowaną kompozycją, coraz częściej urozmaicone fotografiami, które ostatecznie zdominują sposób ich zdobienia w latach sześćdziesiątych i siedemdziesiątych. Zdjęcia prezentowane są $\mathrm{w}$ różnych formatach. Pod koniec lat pięćdziesiątych są to jeszcze niewielkich rozmiarów fotografie wykonawców (śpiewaków) bądź — w wypadku „Błękitnej serii" — obszernej wielkości kadry filmowe z aktorami ekranizacji, dla których powstają piosenki (na przykład Nie trzeba stów — z filmu pt. Zadzwońcie do mojej żony, 1958, reż. Jaroslav Mach) ${ }^{70}$. Oprócz wokalistów zdjęcia ukazują kompo-

65 Protokół I plenarnego posiedzenia Komisji dla Spraw Muzyki Rozrywkowej i Tanecznej dnia 17 października 1955 r., s. 4.

66 Por. Protokół z narady w sprawie wydawnictwa muzyki rozrywkowej z dnia 14 lutego 1958 r., Komisja do spraw Muzyki Rozrywkowej i Tanecznej. Protokoły z posiedzeń, AZKP, sygn. 12/69.

67 Numery „Śpiewamy i tańczymy” prezentowały zwykle kilka piosenek znanych z anteny radiowej (w wykonaniu sławnych wokalistów) oraz artykuły lub notki na temat kompozytorów, wydarzeń muzycznych czy słynnych aranżacji. W pierwszym numerze ukazuje się między innymi Sto lat Szpilmana oraz To idzie miłość Sygietyńskiego i Siedem róż Maklakiewicza. W numerze 3 z 1945 roku Pójdę na stare miasto, Gdy się kogoś ma Szpilmana. W latach 1954-1962, w których ukazało się prawie 200 numerów, opublikowano około 50 piosenek Szpilmana (w kolejnych latach mniej).

68 Zob. https://bibliotekapiosenki.pl/publikacje/Szpilman_Wladyslaw_Warszawskie_refreny; https://bibliotekapiosenki.pl/publikacje/Szpilman_Wladyslaw_Al_Legro_To_niedziela_w_Kazi mierzu (dostęp: lipiec 2021).

69 Terminu „Zwierciadło” (rozumianego jako środkowa, okolona bordiurą, część kompozycji graficznej) używam za J. Górskim, op. cit., s. 15.

70 Zob. https://bibliotekapiosenki.pl/publikacje/Szpilman_Wladyslaw_Al_Legro_Nie_trzeba_ slow_slow-fox_z_filmu_Zadzwoncie_do_mojej_zony (dostęp: lipiec 2021). Przykłady „Błękitnej serii" dostępne w CBPP obejmują wiele innych piosenek Szpilmana, jak choćby Modemoiselle (z filmu Zadzwońcie do mojej żony), Mgła, Nie wierzę piosence. Zob. https://bibliotekapiosenki.pl/ publikacje/Szpilman_Wladyslaw_Al_Legro_Mademoiselle_slow-fox_z_filmu_Zadzwoncie_do_ 
zytorów (jak w numerze 1 z 1966 roku), wypełniając całą kartę awersu okładki, a formuła druku wzbogaca się o krótkie artykuły i nowinki muzyczne, by w latach osiemdziesiątych znów połączyć ilustratorskie medium graficzne $\mathrm{z}$ fotografią ${ }^{71}$.

\section{Okładki piosenek z lat pięćdziesiątych wydawanych przez PWM poza serią}

Poza wydaniami w ramach serii utwory Szpilmana ukazują się także w wersjach indywidualnie zdobionych przez etatowych grafików PWM: Kazimierza Wojtanowicza, Witolda Skulicza, Janusza Bruchnalskiego czy Andrzeja Darowskiego i Andrzeja Kowalskiego, skrywających się pod pseudonimem Andrzej Darkow ${ }^{72}$.

Projekty graficzne oprawy piosenek z pierwszej połowy lat pięćdziesiątych charakteryzuje użycie skrótowych, prostych znaków mieszczących w sobie pozytywne konotacje semantyczne tekstu lub tytułu piosenki, odległe od pompatycznych formalnych rozwiązań i jaskrawych ideologicznie symboli, bliskie estetyce przeznaczonej dla młodocianego odbiorcy lub sztuce plakatu. Na przykład nuty piosenki Kilka słów serdecznych (sł. K. Winkler), której tytułowe słowa zgodnie $\mathrm{z}$ dalszym tekstem piosenki ,w kopercie z małym znaczkiem rozchmurzą twoje oczy" opatrzone są okładką projektu Kazimierza Wojtanowicza, zakomponowaną na kształt pocztowego stempla (jego pieczęć zawiera nazwiska autorów) ${ }^{73}$. Grafika do piosenki Trzej przyjaciele z boiska (sł. A. Międzyrzecki, PWM 1954) - autorstwa J. Kurkiewicza ukazuje symbol czarnej piłki na zielonym tle (wyróżniony dwoma poziomymi pasami bieli) ${ }^{74}$. Indywidualne kroje czcionek nadają im specyficznego, ,animowanego", lekkiego charakteru.

Flagowy utwór tego okresu Czerwony autobus — na okładce według projektu sygnowanego jako A. Darkow ukazuje znak autobusowy, w który wpisano tytuł, wykorzystując koincydencje graficzne szyldu i refrenowego słowa piosenki (il. 5). Czerwono-biały drogowskaz tworzy centralną figurę przedstawienia, tło zaś (podzielone na dwie strefy) przypomina rozwiązanie i kolorystykę innych okładek

mojej_zony; https://bibliotekapiosenki.pl/publikacje/Szpilman_Wladyslaw_Al_Legro_Mgla_slowfox_z_repertuary_Slawy_Przybylskiej; https://bibliotekapiosenki.pl/publikacje/Szpilman_Wladys law_Al_Legro_Nie_wierze_piosence_walc_z_repertuaru_Hanki_Skarzanki (dostęp: lipiec 2021).

$\overline{7}_{1} \bar{Z}$ ob. okładkę proj. Wojciecha Kwaśniewskiego z zeszytu „Ś́piewamy i tańczymy” 1983, nr 4, w J. Nowicka, 70 na 70. Projektowanie graficzne w PWM w latach 1945-2015, Kraków 2015, s. 73.

72 Autorów ukrywających się pod pseudonimem artystycznym Darkow (łączącym nazwiska Darowskiego i Kowalskiego) wskazuje Justyna Nowicka; por. eadem, Pole widzenia. Kilka uwag o projektowaniu graficznym w PWM-ie, [w:] 70 na 70, s. 12-13.

73 Zob. https://bibliotekapiosenki.pl/publikacje/Szpilman_Wladyslaw_Al_Legro_Kilka_slow_ serdecznych_na_glos_z_fortepianem (dostęp: lipiec 2021).

74 Zob. https://bibliotekapiosenki.pl/publikacje/Szpilman_Wladyslaw_Al_Legro_Trzej_przyja ciele_z_boiska_na_glos_z_fortepianem (dostęp: lipiec 2021). 
z tego okresu podpisanych pseudonimem Darkow (na przykład pieśni W. Lutosławskiego Kto pierwszy ${ }^{75}$ ). Wymienione kompozycje stronią od przestawień realistycznych, w tym od prezentowania konkretnych bohaterów swoich czasów, operują pomysłowym skojarzeniem i liternictwem ukazanym w manierze bliskiej rysunkowym realizacjom bajek animowanych.

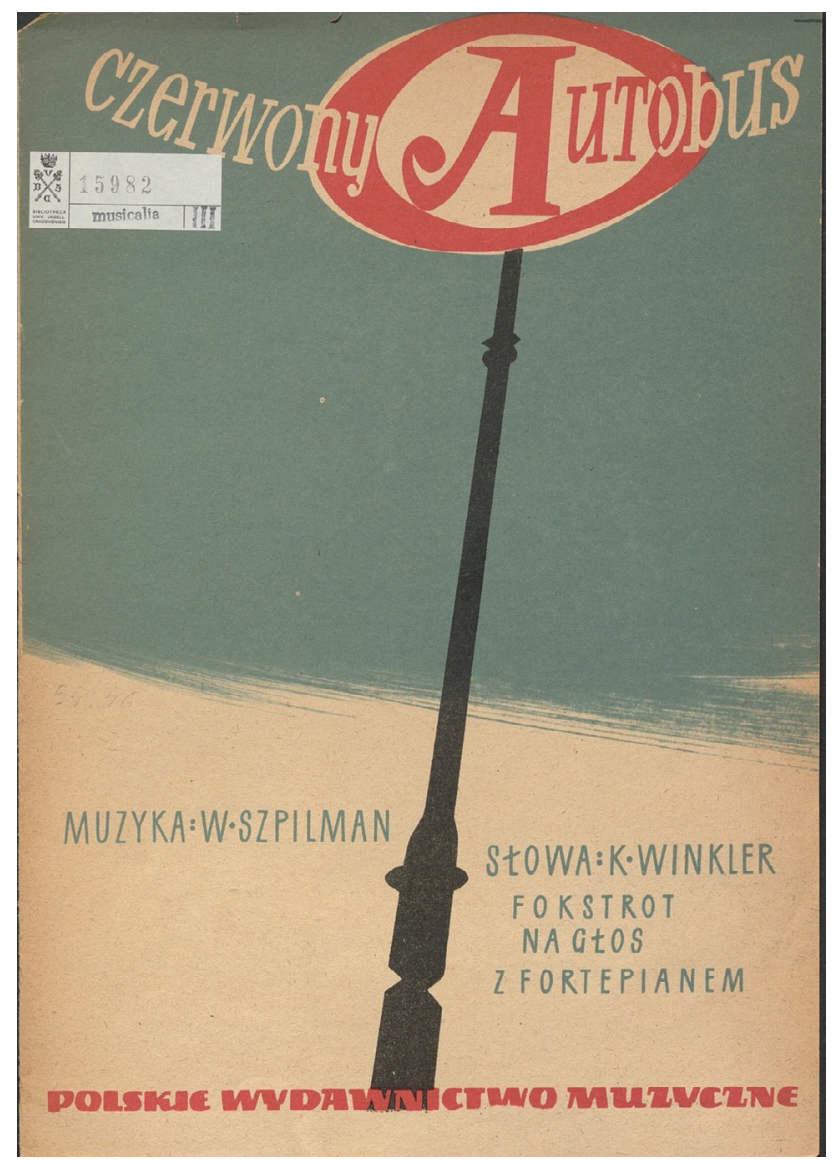

Ilustracja 5. Awers okładki proj. A. Darkow: fokstrot Czerwony autobus, muz. W. Szpilman, sł. K. Winkler, PWM, Kraków 1954

Źródło: skan, dzięki uprzejmości Biblioteki Jagiellońskiej (Zbiory Muzyczne).

Innym przykładem, w którym czytelna jest kreska ilustratorska i typograficzna duetu Darowski-Kowalski (Darkow), jest piosenka Gdy się kogoś ma (sł. Z. Gozdawa, W. Stępień, PWM 1954). W projekcie zwraca uwagę dbałość o różnorodność wzorów liter i rysunkową lapidarność figuralną. Grafitowa okładka ozdobiona jest dwoma rysunkami: dziewczęcej postaci z czterolistną koniczyną i bukietu

75 Zob. https://bibliotekapiosenki.pl/publikacje/Czachorowski_Stanislaw_Swen_Kto_pierwszy_ piosenka_wojskowa (dostęp: lipiec 2021). 
kwiatów, umieszczonych w przeciwległych rogach kompozycji na żółtym tle ${ }^{76}$. Skrótowy sposób przedstawienia postaci kobiecych charakterystyczny jest i dla innych projektów sygnowanych nazwiskiem Darkow, zdradzając indywidualną „kreskę" autorów (łączenie techniki piórka i „pędzla”) 77 .

Odmiennym typem okładki, łączącym nowoczesne cechy medium fotograficznego z modernistycznym układem geometrycznym, jest wydanie fortepianowej wersji cyklu wariacji Jej pierwszy bal w formie piosenki z filmu pt. Epizod (PWM 1957). Utwór skomponowany w getcie warszawskim jako cykl wariacji na głos, dwa fortepiany i orkiestrę wydano pod koniec lat pięćdziesiątych w wersji na głos i fortepian w okładce autorstwa Skulicza. Projekt wykorzystuje zdjęcie postaci kobiecej w balowej sukni, ukazanej na tle „wirującego" okręgu zbudowanego z nieregularnych kolorowych figur układających się na kształt kalejdoskopowego wzoru. Geometryczną kompozycję wyłaniającą się z czarnego tła uzupełniają porozrzucane niesymetrycznie niewielkich kształtów żółte i czerwone figury (trójkąty i prostokąty) (il. 6). Kompozycja przywodzi na myśl skojarzenia z typograficznymi okładkami Jana Młodożeńca ${ }^{78}$, Stanisława Kaźmierczyka ${ }^{79}$. Ekspresjonistyczną gwałtowność figur zastępuje tu układ wiru będący aluzją do tanecznych walorów utworu.

Indywidualny charakter oprawy Jej pierwszego balu widać także, gdy zestawimy ją z innymi opracowaniami graficznymi Skulicza do piosenek tego okresu ${ }^{80}$. Okładka - mimo powinowactw z manierą cechującą oprawy do innych piosenek (formuła lustrzanych bądź wielowymiarowych kształtów i kompozycji „kolistej”) - za sprawą włączenia fotografii odsyła do specyfiki utworu i jego oryginalnej adaptacji filmowo-muzycznej; bliska jest kompozycjom fotomontażowym.

$\mathrm{Z}$ kolei oprawa graficzna muzyki do komedii muzycznych wydawana w formie niewielkich broszur teatralnych czy nut drukowanych bezpośrednio w prasie lub wydaniach książkowych bliska jest sztuce plakatu i satyrycznym rysunkom prasowym; pozostaje wierna idei skrótowej, pomysłowej plastycznej aluzji. Okładki te odzwierciedlają często humorystyczny rys utworu (komediowych wodewili), jak w wypadku publikacji programu komedii muzycznej Mąz Fottasiówny (broszura do przedstawienia Teatru Dolnośląskiego, 1958/1959) bądź specyficzną reprezentację danej instytucji (na przykład warszawskiego Teatru Syrena, PWM 1959) ${ }^{81}$.

76 Zob. https://bibliotekapiosenki.pl/publikacje/Szpilman_Wladyslaw_Al_Legro_Gdy_sie_ko gos_ma_na_glos_z_fortepianem (dostęp: lipiec 2021).

$\overline{7} 7 \bar{Z}$ ob. https://bibliotekapiosenki.pl/publikacje/Szeligowski_Tadeusz_Piosenka_o_trzech_Mau retankach (dostęp: lipiec 2021).

78 Por. okładka Jana Młodożeńca do książki Johna Steinbecka Perła, Czytelnik 1956.

79 Por. okładka proj. Stanisława Kaźmierczyka do książki pt. Kultura świecka $w$ dziejach naszego narodu, Książka i Wiedza 1959.

80 Zob. https://bibliotekapiosenki.pl/publikacje/Swiecicki_Mieczyslaw_Oczy_czarne_Dwie_ gitary_dwa_romanse_rosyjskie_na_glos_z_fortepianem.

$81^{-}$Druk PWM z 1959 roku według projektu Janusza Bruchnalskiego dostępny jest w CBPP. Zob. https://bibliotekapiosenki.pl/publikacje/Szpilman_Wladyslaw_Al_Legro_Kocha_nie_kocha_ Sport_sport_sport_panowie_Tak_malo_sie_znam (dostęp: lipiec 2021). 


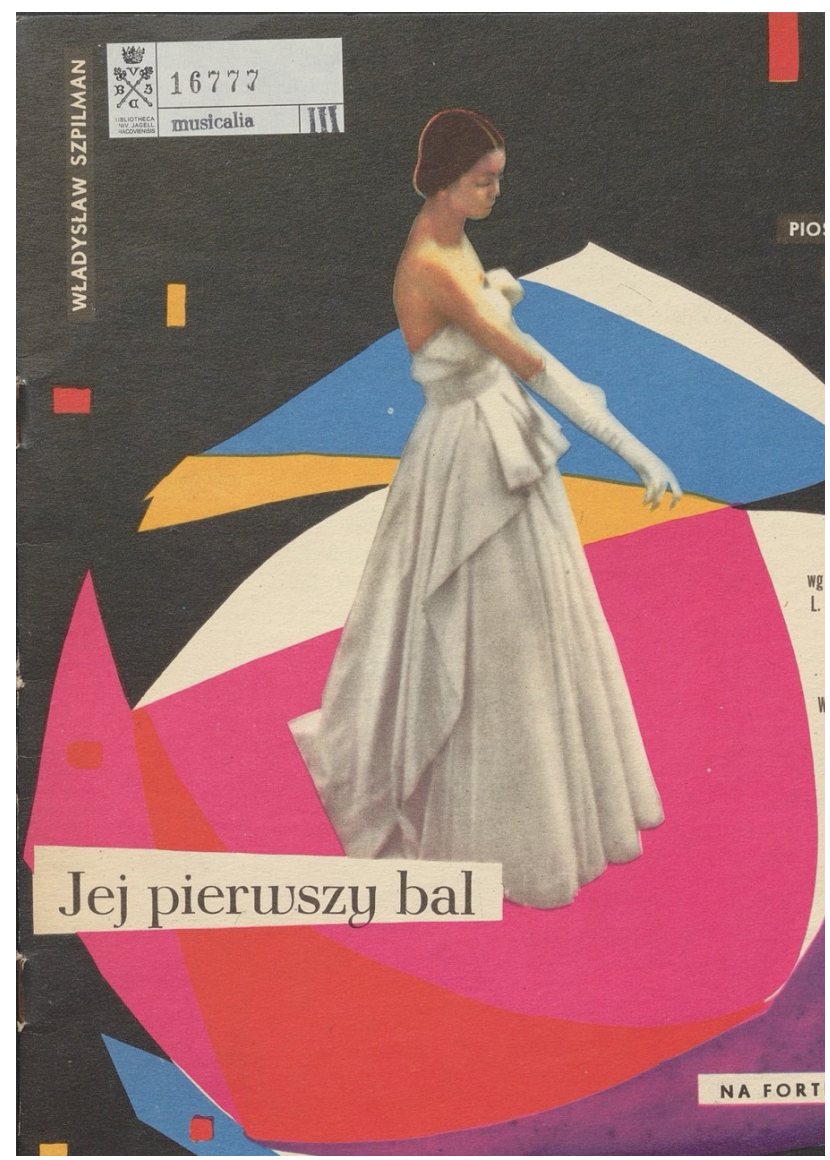

Ilustracja 6. Awers okładki według proj. Witolda Skulicza: Jej pierwszy bal. Piosenki z filmu „Epizod”, muz. W. Szpilman, sł. B. Brok, W. Schlengel, PWM, Kraków 1957

Źródło: skan, dzięki uprzejmości Biblioteki Jagiellońskiej (Zbiory Muzyczne).

Ich walory plastyczne - w rysunkowej manierze karykaturalnej bądź malarsko-syntetycznej - przykuwają uwagę, dopełniają charakteru utworu, pełnią funkcję atrakcyjnego plastycznego znaku. Są śladami niecyfrowego rzemiosła i rozpoznawalnej marki artysty grafika.

Wspomniane przykłady oraz projekty autorów związanych z wydawnictwem PWM (okładki nieseryjne) kontrastują z wczesnymi klasycyzującymi i o dość jednorodnej formule okładkami Czytelnika do pieśni Szpilmana z początku lat pięćdziesiątych. Wyróżniają się różnorodnością technik i rozwiązań formalnych, indywidualnością formy i krojów liter, malarskością gestu i ciekawym ujęciem tematu. Podobnie jak te pochodzące z Czytelnika zachowują równowagę i proporcję poszczególnych elementów kompozycji, dodatkowo wprowadzając między innymi swobodę, wielobarwność i oryginalność (za sprawą zróżnicowanych osobistości grafików) daleką od stylistyki socrealistycznej. Cechy te są i w oprawach 
oraz ilustracjach książek początku ,złotego okresu polskiej ilustracji”, nierzadko realizowanych z myślą o młodym odbiorcy (o którego z jednej strony zabiegał mecenat państwowy, z drugiej strony będącym dla artystów grafików wdzięcznym adresatem pozwalającym na realizację projektów pozbawionych ,ideowych problemów"82). Przytoczone publikacje nutowe - jak wynika z ich szaty graficznej — również nosiły znamiona „młodzieńczej fantazji” ${ }^{83}$ (początek lat pięćdziesiątych) i następnie intrygującego charakteru atrakcyjnego dla odbiorcy szeroko rozumianej oferty kultury (literackiej, muzycznej, artystycznej).

\section{Przemiany stylistyczne oprawy graficznej piosenek po roku 1960: Synkopa, PWM i Wydawnictwo Muzyczne Agencji Autorskiej}

Warto zwrócić również uwagę na rozwój graficznych trendów w projektowaniu okładek do utworów popularnych kolejnych dekad, widoczny we wszystkich typach piosenek (dziecięcych, rozrywkowych) i na trwałość formy wydawniczej o charakterze serii.

O ile okładki zeszytów z piosenkami dziecięcymi Szpilmana z lat 1951-1952 zdobione były klasycznym szkicowym rysunkiem (Czytelnik), o tyle nuty utworów dla dzieci z początku lat sześćdziesiątych uderzają oprawą pełną barw i niedosłownych stylizacji. Niezmiennym elementem w projektowaniu pozycji przeznaczonych dla młodszego czytelnika pozostaje prostota rysunku, który w starszych publikacjach wypełnia proporcjonalnie mniejszą część druku (względem zapisu nutowego). Młodsze propozycje z muzyką dla dzieci opatrzone są ilustracjami tworzącymi atrakcyjne uzupełnienie nut i jednocześnie integralną część interesująco zakomponowanych okładek. W projekcie Jerzego Srokowskiego do nut wydanych przez Synkopę nie ma podziału na wyodrębniającą się część ilustracyjną i inskrypcyjną. Tytuł druku umieszczono na będącym częścią ilustracji pulpicie fortepianu, tworzącym swoisty obraz w obrazie. Instrument zaprezentowano w formie łączącej ornamentalne szkicowe detale konstrukcji z pasmem koloru przecinającym okładkę na dwie strefy i znaczącym figurę fortepianu. Widoczna na awersie postać dziewczęca trzyma w dłoni kartę tytułową nut umieszczonych na pulpicie, druga postać dziewczęca — z nutami pod ręką — przedstawiona jest na rewersie, z któ-

82 Por. A. Wincentiusz-Patyna, Stacja ilustracja. Polska ilustracja ksiązkowa 1950-1980. Artystyczne kreacje i realizacje, Wrocław 2008, s. 37-57.

83 Więcej o swoistej praktyce (wśród polskich grafików zatrudnionych w PWM) unikania dydaktyzmu i literalności przekazu oraz typowego socrealistycznego stylu pisze M. Zgliński. Por. idem, Cover design in editions of Polish propaganda songs, 1945-1955, [w:] Music, Politics and Ideology in the Visual Arts, red. P. Gancarczyk, D. Grabiec, Warszawa 2015 (Ikonografia muzyczna. Studia i materiaty, t. 3). 
rym frontowa ilustracja okładki tworzy całość. Sylwetki dzieci oddano również za pomocą wielobarwnych geometryzujących form i rysunkowych detali (il. 7). Pomysłowo zakomponowany tytuł druku jest jednocześnie nawiązaniem do historycznej, kolorowej serii wydawniczej Naszej Księgarni pt. „Poczytaj mi, mamo” (obecnie wydawanej również w wersji „Opowiem ci, mamo”), a geometryczne stylizacje występują i w innych ilustracjach wewnątrz druku.

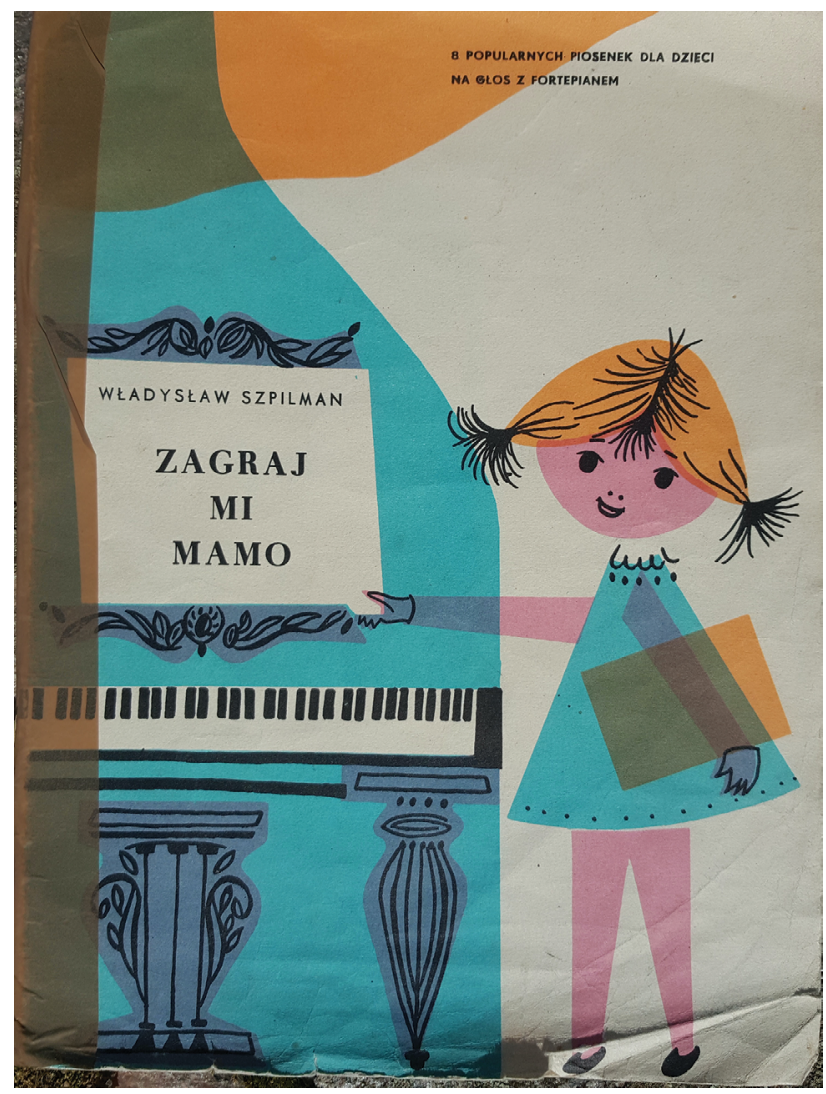

Ilustracja 7. Awers okładki według proj. Jerzego Srokowskiego: W. Szpilman, Zagraj mi mamo:

8 popularnych piosenek dla dzieci na głos z fortepianem, Synkopa, Warszawa 1961

Źródło: fot. K. Staśko-Mazur, zbiory prywatne.

Okładki piosenek popularnych wydawanych w PWM w kolejnych latach także zmieniają charakter i ideę wzornictwa. Fokstrot pt. Oddaj mi każdy dzień (cop. 1960) opatrzony jest oprawą graficzną projektu Janusza Bruchnalskiego ${ }^{84}$, której symbolika podejmuje wybrane treści piosenki (minione dni i noce) za pomocą niekonwencjonalnej realizacji (niedosłownej aluzji łączącej różne style). Skrawki

84 Janusz Bruchnalski jest także autorem okładki do Piosenki mariensztackiej Szpilmana (1954, PWM). 
nieba „wydarte” kolażowo, z geometrycznym „nadrukowanym” (niemal popartowym) wzorem lub szrafowane „rytym” światłocieniem, z emblematem słońca $\mathrm{w}$ formie stempelkowej zawieszone są na ciemnym tle awersu okładki. Z kompozycją kontrastuje zapis tytułu ujęty w specyficzne „naiwne” liternictwo (zdobione różowymi ikonami serc), zdradzające miłosną tematykę ,radiowej piosenki miesiąca" (październik 1960) (il. 8).

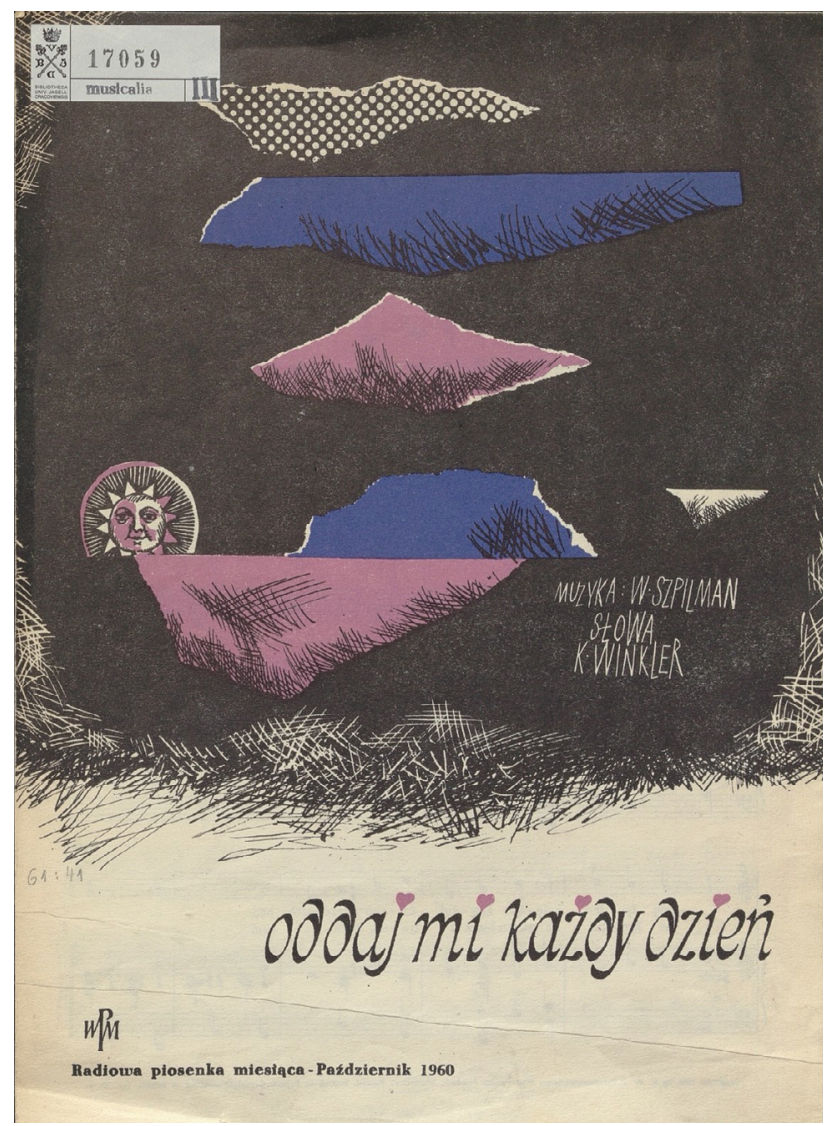

Ilustracja 8. Awers okładki proj. Janusza Bruchnalskiego: Oddaj mi każdy dzień, muz. W. Szpilman, sł. K. Winkler, PWM, 1960

Źródło: skan, dzięki uprzejmości Biblioteki Jagiellońskiej (Zbiory Muzyczne).

Pod koniec lat osiemdziesiątych utwory Szpilmana wydawane wcześniej w PWM ukazują się we wznowieniach innych oficyn. Wydawnictwo Muzyczne Agencji Autorskiej (dalej: AA) w modernistycznej konwencji i na nietypowym formacie (mniejszym niż dotychczasowe druki A4) prezentuje między innymi bluesa Do widzenia Teddy, Piosenke z calusem czy W matym kinie $(1983)^{85}$.

85 Zob. https://bibliotekapiosenki.pl/publikacje/Szpilman_Wladyslaw_Al_Legro_W_malym_ kinie (dostęp: lipiec 2021). 
Seria AA (często z hasłem ,przebój sprzed lat”) opatrzona jest grafiką autorstwa Waldemara Andrzejewskiego w formie geometrycznej kompozycji o trójwymiarowym efekcie optycznym, która — jak łatwo zgadnąć — nie jest związana z tytułami utworów. Modyfikacji w kolejnych zeszytach podlega jedynie kolor kompozycji figur, nadając piosenkom wydanym w kolejnych zeszytach status serii (il. 9).

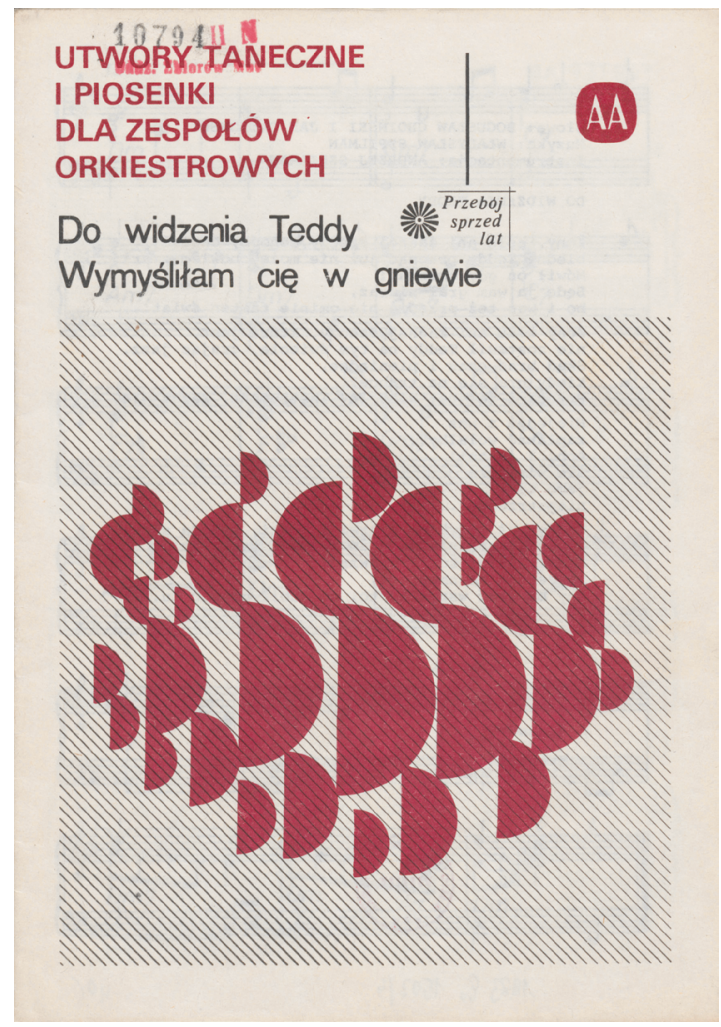

Ilustracja 9. Awers okładki proj. Waldemara Andrzejewskiego z serii „Utwory taneczne i Piosenki dla Zespołów Orkiestrowych": Do widzenia Teddy, muz. W. Szpilman, Wydawnictwo Muzyczne Agencji Autorskiej, Warszawa 1983

Źródło: skan, dzięki uprzejmości Biblioteki Uniwersytetu Wrocławskiego, Oddział Zbiorów Muzycznych, sygn. 10794 II N.

Abstrakcyjne projekty, w których zamiast dosłowności przedstawień figuralnych artyści operują formami geometrycznymi, rytmicznością układu kompozycji lub modulacją barw, nie były obce oprawie graficznej muzyki współczesnej — miały swe stałe miejsce wśród okładek na przykład do muzyki sonorystycznej wydawanych przez $\mathrm{PWM}^{86}$. O wprowadzeniu nowoczesnych okładek w wydaw-

86 Zob. okładkę Janusza Bruchnalskiego do II Symfonii W. Lutosławskiego (PWM, 1969) czy projekt Janusza Wysockiego do Albumu Miniatur na skrzypce i fortepian, red. E. Umińskiej (PWM 1971), [w:] J. Nowicka, 70 na 70, s. 24, 66. 
nictwie na przełomie lat pięćdziesiątych i sześćdziesiątych wspomina Mieczysław Tomaszewski: „gdy pojawiła się polska awangarda, dyrektor Ochlewski powziął myśl zwrócenia uwagi na polskie partytury sonorystyczne przez wyposażenie ich w barwne, zwracające uwagę okładki" ${ }^{87}$. Dbałość o ich jakość jako element rozpoznawalnej marki wspomina także graficzka Lidia Bruchnalska: „Ochlewski był patriotą, chciał pokazywać na świecie polską muzykę, łącząc ją z osiągnięciami najlepszych polskich grafików" ${ }^{\prime 8}$.

Co interesujące, echa tej oryginalnej maniery zdobnictwa odnajdujemy i w późniejszym okresie właśnie w wydawnictwach muzyki rozrywkowej, do których przenikają abstrakcyjne motywy, nadając zeszytom muzyki lekkiej odmienny (nowoczesny) charakter.

Wśród cech, które zdają się prymarne i charakterystyczne dla wszystkich wydawców bądź propagatorów repertuaru popularnego, była praktyka edycji piosenek $\mathrm{w}$ formie druku ukazującego się $\mathrm{w}$ jednym czasie $\mathrm{z}$ promocją danego utworu na deskach teatrów rewiowych, falach eteru, ekranach kin czy z wydaniem fonograficznym. Dbałość o drukowanie „prawdziwych przebojów” i reklamę na kartach nut ich wersji fonograficznych widoczna jest szczególnie wśród oficyn lat trzydziestych. Formuły tych druków miały charakter daleki od secesyjnych, wyrafinowanych, ornamentalnych, kompozycji ilustratorskich. Zaprojektowane są raczej na wzór prasowych nowości prezentujących na okładkach wizerunki twórców najświeższych produkcji (śpiewaków, kompozytorów, aktorów), a nie finezyjnie przedstawionych bohaterów pieśni. Dla Szpilmana, jako redaktora radiowego i współtwórcy lansującego repertuar radiowy, aktualność druku była tak palącą potrzebą, że wraz z innymi kompozytorami (po wojnie) nawoływał do powołania specjalnego wydawnictwa "gazetowego" nadążającego za żywym rynkiem muzyki popularnej, nawet kosztem bogatej szaty graficznej druku. Wydaje się, że tropem tym podążały w swoim tempie i wydawnictwa późniejsze, państwowe.

Efektem dążenia do punktualności wydawniczej względem aktualnej popularności przeboju stała się więc praktyka producentów wydawców do wydawania piosenek w okładce seryjnej lub wariantowanej, o rozpoznawalnej oprawie. Projekty litografii tego typu serii zdradzają okres ich powstania. Oficyna Arcta stosowała jeszcze przedwojenny dynamiczny, big-bandowy sztych w tradycyjnym centralnym układzie, Nowa Scena nowoczesny, barwiony, prasowy wzór graficzny á la art déco, a w druku wydawnictwa Ton eksponowano fotografie. Czytelnik i PWM w pierwszych latach działalności stosują klasycyzujące bordiury i winiety, z czasem formułę zdjęć łączonych z grafiką (,Śpiewamy i tańczymy”), Wydawni-

87 J. Nowicka, Pole widzenia, s. 9.

88 Ibidem. 
ctwo Muzyczne Agencji Autorskiej zaś przedstawienia geometryczne nawiązujące do stylistyki awangardy. Praktyka tego typu zdobnictwa powołała do życia swoiste kolekcje druków, których design jest symptomatyczny dla danego wydawnictwa.

Ograniczenie rynku wydawniczego do państwowych instytucji skutkuje ujednoliceniem oprawy graficznej druków do kilku form, których różnorodność plastyczna objawia się raczej $\mathrm{w}$ ramach odmiennych podgatunków (piosenka popularna, filmowa, dla dzieci) i rodzaju druku (nuty na głos i fortepian, wydanie okolicznościowe, Czytelnik).

Charakter okładek zdobionych ilustracjami naznaczona jest także piętnem swojego czasu, oczekiwaniami wydawców i nadzorców kultury, możliwościami realizacyjnymi wydawnictw i twórców. Projekty plakatowe, jedno- lub dwubarwne, o uogólnionej motywice przeważają na przełomie lat czterdziestych i pięćdziesiątych. Ich ilustracje nawiązują bądź do tytułu, bądź - w wybranych pieśniach masowych tego okresu - eksponują cechy formalne (oficjalna symbolika w marszu Ludzie walki i pracy) czy w wyjątkowych przypadkach wątki socrealistyczne (Walczyk murarski). Obecne w wybranych tekstach piosenek jaskrawe socrealistyczne lub patriotyczne elementy języka nie zawsze jednak ujawniano na okładkach (Morskie orły proj. Skulicza, Czytelnik 1952, Walczyk murarski na orkiestrę taneczną, Wydawnictwo M. Arcta), a wybrane pieśni pozbawione socrealistycznych treści bywały z kolei wykluczane przez władze z rozpoczętej produkcji w prywatnych oficynach wydawniczych (Ku tobie plynie melodia ta, Wydawnictwo E. Kuthan).

Taneczne piosenki Szpilmana z połowy lat pięćdziesiątych zdobione są indywidualnymi wielobarwnymi okładkami grafików PWM i w warstwie wizualnej pozostają wierne witalistycznym elementom tekstów/tytułów w pomysłowej formie graficznego plakatowego znaku kierowanej ku młodemu odbiorcy. Okładki z przełomu lat pięćdziesiątych i sześćdziesiątych ukazują bardziej niezależny (od jednoznacznie optymistycznej wizji) design, często oryginalnie łączący różne techniki plastyczne (graficzne, fotograficzne, liternicze) i aluzje literackie.

Do ciekawych należy zjawisko przenikania do okładek piosenek popularnych niektórych trendów cechujących druki innych gatunków (na przykład sposoby ilustrowania muzyki sonorystycznej przez PWM) czy zmiana konwencji w ilustrowaniu okładek utworów dla dzieci (Synkopa). Różnorodność form ich zdobienia nie pozwala na wyłonienie jednego, charakterystycznego tylko dla utworów Szpilmana stylu opraw. Wręcz przeciwnie, twórczość muzyka posłużyć może jako repozytorium wiedzy, mówiącej o meandrach sztuki drukarskiej w dziedzinie piosenki, zmiennych praktykach jej twórców i swoistej sposobności druków do wizualnego oddziaływania na jej odbiorców. 


\section{The graphic design of sheet music covers for popular songs by Władysław Szpilman as an example of artistic and publishing practices and cover design evolution}

\section{Abstract}

This paper discusses the graphic design of sheet music covers for popular songs by Władysław Szpilman, focusing on various decoration patterns and design trends as well as on the evolution of the design of Polish popular sheet music covers.

A selection from a large body of Szpilman's sheet music is investigated, published before World War II by privatively-owned or cooperative publishers such as Nowa Scena, Arct's Music Publishing House (Wydawnictwo Muzyczne Arcta), E. Kuthan's Publishing House (Wydawnictwo E. Kuthana), and Ton, which, after 1945, were displaced by state-owned businesses. The author discusses different decoration styles typical for different periods, e.g. the publicity style, the bordure-vignette style, the lettering-typographic style, and the poster style, exploring the complexities of the processes of ideologizing the role of art (e.g. the different ways of illustrating Socialist Realist period songs for individual customers and for musical groups; Czytelnik's modest and graphically uniform publications). After World War II, Szpilman was among the proponents of the idea of creating a newspaper-type popular music series, which would keep abreast of the times by publishing music sheets for currently popular songs. At the same time, covers for Szpilman's sheet music were designed by eminent graphic designers working for the Polish Music Publishing House (Polskie Wydawnictwo Muzyczne): W. Skulicz, J. Bruchnalski, A. Darowski, A. Kowalski, K. Wojtanowicz, and J. Kurkiewicz, among others. After examining a wide variety of sheet music covers, the author identified a number of publishing practices (such as creating a series or a sheet music collection), noticing an aesthetic evolution of cover design for particular publishers and over time (e.g. in the way music for children and adolescents was illustrated), and a migration of modern graphic motifs from other musical genres, such as Sonorism.

Keywords: graphic design of sheet music, popular music covers, W. Szpilman, A. Darowski, A. Darkow, J. Bruchnalski, W. Skulicz, A. Kowalski, E. Kuthan, Wydawnictwo Muzyczne Arcta, Nowa Scena, Czytelnik, PWM, Synkopa, Wydawnictwo Muzyczne Agencji Autorskiej, publishing house Ton, changes in cover design

\section{Bibliografia}

Boruc A., Michat Arct. Dylematy warszawskiego księarza-wydawcy schyłku XIX wieku, „Sztuka Edycji” 2013, nr 4.

Ciszewska W.A., Źródta do badań nad dziejami książki lat 1945-1950, „Biuletyn EBIB” 2007, nr 1. Górski J., Dosłownie. Liternicze i typograficzne okładki polskich książek 1944-2019, Kraków 2019.

Lerski T., Encyklopedia kultury polskiej XX wieku. Muzyka — teatr - film, t. 1. Muzyka mechaniczna-pierwsze czterdziestolecie, Warszawa 2007.

Lerski T., Rola radia, filmu i fonografi w popularyzowaniu polskiej piosenki $w$ dwudziestoleciu międzywojennym, „Piosenka” 2014, nr 2.

Lerski T., Syrena Record - pierwsza polska wytwórnia fonograficzna. Poland's first recording company 1904-1944, New York-Warszawa 2004. 
Nowicka J., 70 na 70. Projektowanie graficzne w PWM w latach 1945-2015, Kraków 2015.

Nowicka J., Pole widzenia. Kilka uwag o projektowaniu graficznym w PWM-ie, [w:] idem, 70 na 70. Projektowanie graficzne w PWM w latach 1945-2015, Kraków 2015.

Sempoliński L., Wielcy artyści matych scen, Warszawa 1968.

Sitarz A., W cieniu Polskiego Wydawnictwa Muzycznego. O kilku polskich wydawnictwach prywatnych działających $w$ dziedzinie muzyki po II wojnie światowej do początku lat pięćdziesiatych, [w:] Muzykolog wobec świadectw źródłowych i dokumentów. Księga pamiątkowa dedykowana profesorowi Piotrowi Poźniakowi w 70. rocznicę urodzin, red. Z. Dobrzańska-Fabiańska, Kraków 2009.

Staśko-Mazur K., Pieśni masowe Władysława Szpilmana w kontekście dorobku piosenkarskiego kompozytora, „Res Facta Nova” 2020, nr 21.

Szafa grajaca. Żydowskie stulecie na szelaku i winylu. Historie z Polski, red. T. Sztyma, M. Prokopowicz, Warszawa 2017.

Szpilman W., Moje życie, „Ekspress” 8.04.1988.

Tomkins D.G., Composing the Party Line. Music and Politics in Early Cold War Poland and East Germany, Indiana 2013.

Wincencjusz-Patyna A., Stacja ilustracja. Polska ilustracja książowa 1950-1980. Artystyczne kreacje i realizacje, Wrocław 2008.

Zgliński M., Cover design in editions of Polish propaganda songs, 1945-1955, [w:] Music, Politics and Ideology in the Visual Arts, red. P. Gancarczyk i D. Grabiec, Warszawa 2015 (Ikonografia muzyczna. Studia i materiaty, t. 3).

\section{Archiwalia Związku Kompozytorów Polskich, Komisja d/s Muzyki Rozrywkowej i Tanecznej. Protokoły z posiedzeń. 1954-57, sygn. 12/69}

Protokół z posiedzenia Komisji dla spraw Muzyki Rozrywkowej i Tanecznej przy Związku Kompozytorów Polskich — w dniu 5 czerwca $1954 \mathrm{r}$.

Protokół nr 2 z posiedzenia plenarnego Komisji dla Spraw Muzyki Rozrywkowej i Tanecznej przy ZKP w dniu 9 czerwca 1954 r.

Protokół nr 3 z posiedzenia plenarnego Komisji dla Spraw Muzyki Rozrywkowej i Tanecznej przy ZKP w dniu 12 czerwca $1954 \mathrm{r}$.

Protokół nr 14 z posiedzenia plenarnego Komisji dla Spraw Muzyki Rozrywkowej i Tanecznej przy ZKP w dniu 15 października $1954 \mathrm{r}$.

Protokół nr 17 z posiedzenia plenarnego Komisji dla Spraw Muzyki Rozrywkowej i Tanecznej przy ZKP w dniu 14.XII.1954 r.

Protokół I plenarnego posiedzenia Komisji dla Spraw Muzyki Rozrywkowej i Tanecznej dnia 17 października $1955 \mathrm{r}$.

Wniosek Komisji Muzyki Rozrywkowej i Tanecznej do Zarządu Głównego Związku kompozytorów Polskich z 26 kwietnia 1957 roku.

List Państwowego Przedsiębiorstwa Obrotu Księgarskiego „Dom Książki” do Spółdzielni usługowej „Znak” z dnia 15 września 1957 r.

List Usługowej Spółdzielni Pracy „Znak” do Zarządu Związku Kompozytorów Polskich z dnia 7 stycznia 1958.

Protokół z narady w sprawie wydawnictwa muzyki rozrywkowej z dnia 14 lutego $1958 \mathrm{r}$.

Stenogram z narady w sprawie aktualnych problemów muzyki tanecznej i rozrywkowej w dniu 22 maja 1954 r., sygn. 12/68. 
Kamila Staśko-Mazur — zajmuje się dźwiękiem w perspektywie muzycznej i środowiskowo-ekologicznej, w praktyce kompozytorskiej i badawczej. Związana z Instytutem Muzykologii, w którym obecnie opracowuje spuściznę kompozytorską Władysława Szpilmana. Współtworzy zespół Pracowni Badań Pejzażu Dźwiękowego (przy Instytucie Kulturoznawstwa Uniwersytetu Wrocławskiego), prowadzi działalność edukacyjną między innymi w ramach Podyplomowych Studiów „Dźwięk i Audiosfera” (przy Instytucie Muzykologii Uniwersytetu Wrocławskiego). Autorka reportaży muzycznych, projektów i realizacji artystycznych o profilu ekologii dźwiękowej. Publikowała w pismach: „Muzyka”, „Ruch Muzyczny”, „Res Facta Nova”, „Argument” i „Audiosfera: Koncepcje - Badania - Praktyki”.

kamila.staskomazur@gmail.com 